\title{
Coordination Chemistry of $\left[\mathrm{HFe}(\mathrm{CN})_{2}(\mathrm{CO})_{3}{ }^{-}\right.$and Its Derivatives: Toward a Model for the Iron Subsite of the [NiFe]-Hydrogenases
}

\author{
C. Matthew Whaley, Thomas B. Rauchfuss, and Scott R. Wilson \\ Department of Chemistry, University of Illinois at Urbana-Champaign, Urbana, IL 61801
}

\section{Abstract}

The photoreaction of $\mathrm{Fe}(\mathrm{CO})_{5}$ and cyanide salts in $\mathrm{MeCN}$ solution affords the dianion $[\mathrm{Fe}$ $\left.(\mathrm{CN})_{2}(\mathrm{CO})_{3}\right]^{2-}$, conveniently isolated as $\left[\mathrm{K}(18 \text {-crown-6) }]_{2}\left[\mathrm{Fe}(\mathrm{CN})_{2}(\mathrm{CO})_{3}\right]\right.$. Solutions of $[\mathrm{Fe}$ $\left.(\mathrm{CN})_{2}(\mathrm{CO})_{3}\right]^{2-}$ oxidize irreversibly at $-600 \mathrm{mV}($ vs. $\mathrm{Ag} / \mathrm{AgCl})$ to give primarily $\left[\mathrm{Fe}(\mathrm{CN})_{3}(\mathrm{CO})_{3}\right]^{-}$. Protonation of the dianion affords the hydride $\left[\mathrm{K}\left(18\right.\right.$-crown-6)][HFe $\left.(\mathrm{CN})_{2}(\mathrm{CO})_{3}\right]$ with a $\mathrm{p} K_{\mathrm{a}} \approx 17$ $(\mathrm{MeCN})$. The ferrous hydride exhibits enhanced electrophilicity vs. its dianionic precursor, which resists substitution. Treatment of $\left[\mathrm{K}(18 \text {-crown-6)][Fe( } \mathrm{CN})_{2}(\mathrm{CO})_{3}\right]$ with tertiary phosphines and phosphites gives isomeric mixtures of $\left[\mathrm{HFe}(\mathrm{CN})_{2}(\mathrm{CO})_{2} \mathrm{~L}\right]^{-}\left(\mathrm{L}=\mathrm{P}(\mathrm{OPh})_{3}\right.$ and $\left.\mathrm{PPh}_{3}\right)$. Carbonyl substitution on $\left[1 \mathrm{H}(\mathrm{CO})_{2}\right]^{-}$by $\mathrm{P}(\mathrm{OPh})_{3}$ is first-order in both the phosphite and iron $\left(k=0.18 \mathrm{M}^{-1}\right.$ $\mathrm{s}^{-1}$ at $22{ }^{\circ} \mathrm{C}$ ) with $\Delta H^{\ddagger}=51.6 \mathrm{~kJ} \mathrm{~mol}^{-1}$ and $\Delta S^{\ddagger}=-83.0 \mathrm{~J} \mathrm{~K}^{-1} \mathrm{~mol}^{-1}$. These ligands are displaced under an atmosphere of $\mathrm{CO}$. With cis $-\mathrm{Ph}_{2} \mathrm{PCH}=\mathrm{CHPPh}_{2}$ (dppv), we obtained the monocarbonyl, $\left[\mathrm{HFe}(\mathrm{CN})_{2}(\mathrm{CO})(\mathrm{dppv})\right]^{-}$, a highly basic hydride $\left(\mathrm{p} K_{\mathrm{a}}>23.3\right)$ that rearranges in solution to a single isomer. Treatment of $\left[\mathrm{K}\left(18\right.\right.$-crown-6)][HFe $\left.(\mathrm{CN})_{2}(\mathrm{CO})_{3}\right]$ with $\mathrm{Et}_{4} \mathrm{NCN}$ resulted in rapid proton transfer to give $\left[\mathrm{Fe}(\mathrm{CN})_{2}(\mathrm{CO})_{3}\right]^{2-}$ and $\mathrm{HCN}$. The tricyano hydride $\left[\mathrm{HFe}(\mathrm{CN})_{3}(\mathrm{CO})_{2}\right]^{2-}$ is prepared by the reaction of $\left[\mathrm{HFe}(\mathrm{CN})_{2}(\mathrm{CO})_{2}\left(\mathrm{PPh}_{3}\right)\right]^{-}$and $[\mathrm{K}(18$-crown-6)]CN. Similar to the phosphine and phosphite derivatives, $\left[\mathrm{HFe}(\mathrm{CN})_{3}(\mathrm{CO})_{2}\right]^{2-}$ exists as a mixture of all three possible isomers. Protonation of the hydrides $\left[\mathrm{HFe}(\mathrm{CN})_{2}(\mathrm{CO})(\mathrm{dppv})\right]^{-}$and $\left[\mathrm{HFe}(\mathrm{CN})_{3}(\mathrm{CO})_{2}\right]^{-}$in acetonitrile solutions releases $\mathrm{H}_{2}$ and gives the corresponding acetonitrile complexes [K(18-crown-6)][Fe $\left.(\mathrm{CN})_{3}(\mathrm{NCMe})(\mathrm{CO})_{2}\right]$ and $\mathrm{Fe}(\mathrm{CN})_{2}(\mathrm{NCMe})(\mathrm{CO})(\mathrm{dppv})$. Alkylation of $\left[\mathrm{K}(18 \text {-crown-6) }]_{2}[\mathrm{Fe}\right.$ $\left.(\mathrm{CN})_{2}(\mathrm{CO})_{3}\right]$ with MeOTf gives the thermally-unstable $\left[\mathrm{MeFe}(\mathrm{CN})_{2}(\mathrm{CO})_{3}\right]^{-}$, which was characterized spectroscopically at $-40{ }^{\circ} \mathrm{C}$. Reaction of dppv with $\left[\mathrm{MeFe}(\mathrm{CN})_{2}(\mathrm{CO})_{3}\right]^{-}$gives the acetyl complex, $\left[\mathrm{Fe}(\mathrm{CN})_{2}(\mathrm{COMe})(\mathrm{CO})(\mathrm{dppv})\right]^{-}$. Whereas $\left[\mathrm{Fe}(\mathrm{CN})_{2}(\mathrm{CO})_{3}\right]^{2-}$ undergoes protonation and methylation at $\mathrm{Fe}$, acid chlorides give the iron $(0) \mathrm{N}$-acylisocyanides $[\mathrm{Fe}(\mathrm{CN})$ $\left.(\mathrm{CO})_{3}(\mathrm{CNCOR})\right]^{-}\left(\mathrm{R}=\mathrm{Ph}, \mathrm{CH}_{3}\right)$. The solid state structures of $\left[\mathrm{K}\left(18\right.\right.$-crown-6)][HFe $(\mathrm{CN})_{2}(\mathrm{CO})$ (dppv)], $\mathrm{Fe}(\mathrm{CN})_{2}(\mathrm{NCMe})(\mathrm{CO})(\mathrm{dppv})$, and $\left[\mathrm{K}(18 \text {-crown-6) }]_{2}\left[\mathrm{HFe}(\mathrm{CN})_{3}(\mathrm{CO})_{2}\right]\right.$ were confirmed crystallographically. In all three cases, the cyanide ligands are cis to the hydride or acetonitrile ligands.

\section{Introduction}

Ferrous carbonyl cyanide complexes have aroused recent interest due to their presence in [FeFe]- and [NiFe]-hydrogenases - metalloenzymes that are responsible for the interconversion of dihydrogen to protons and electrons with high catalytic efficiency. ${ }^{1}$ The active site of the $[\mathrm{FeFe}]$ enzyme features $\mathrm{Fe}(\mathrm{CO})(\mathrm{CN})$ and $\mathrm{Fe}(\mathrm{CO})_{2}(\mathrm{CN})$ sites, and the active site of the $[\mathrm{NiFe}]$ enzyme features a $\mathrm{Fe}(\mathrm{CO})(\mathrm{CN})_{2}$ site. Additionally, mutants of the $[\mathrm{NiFe}]-$ hydrogenases are proposed to contain tricyano $\left(\mathrm{Fe}(\mathrm{CO})(\mathrm{CN})_{3}\right.$-containing centers. $^{2}$ 
The active site of [NiFe]-hydrogenase is composed of a $\mathrm{Ni}$ center coordinated by two terminal and two bridging cysteine thiolates in a highly distorted tetrahedral arrangement and an octahedral Fe atom coordinated by two bridging cysteine thiolates, two cyanides, and a terminal carbonyl. ${ }^{3}$ No bridging ligand has been observed crystallographically in the catalytically relevant reduced forms of the active site; however, a bridging hydride has been detected by ENDOR and HYSCORE spectroscopies. ${ }^{4}$

As indicated in the thorough review by Fehlhammer and Fritz, metal cyanides are reactive toward a broad range of electrophiles (e.g. HX, RX, RCOX), which attack almost exclusively at cyanide. ${ }^{5}$ Such reactivity studies have emphasized mid-valent metal cyanides, which are more widely available, or low valent polycarbonyl cyanides wherein the metal is only weakly basic. It seems likely that low-valent metal cyanides could display metal-centered reactivity, competitive with the $\mathrm{N}$-centered reactions. Indeed, complexes of the type $\mathrm{Rh}^{\mathrm{I}}(\mathrm{chel}) \mathrm{CN}$ (where chel $=\mathrm{N}\left(\mathrm{CH}_{2} \mathrm{CH}_{2} \mathrm{PPh}_{2}\right)_{3}$ and $\left.\mathrm{P}\left(\mathrm{CH}_{2} \mathrm{CH}_{2} \mathrm{PPh}_{2}\right)_{3}\right)$ protonate at $\mathrm{Rh}^{6}$ Similarly, protonation of $\left[\mathrm{Fe}_{2}{ }_{2}(\mathrm{SR})_{2}(\mathrm{CN})_{2}(\mathrm{CO})_{4}\right]^{2-}$ and $\left[\mathrm{Fe}_{2}{ }_{2}(\mathrm{SR})_{2}(\mathrm{CN})(\mathrm{CO})_{4}\left(\mathrm{PMe}_{3}\right)\right]^{-}$occurs at the iron, ${ }^{7}$ not at $\mathrm{FeCN}$, although in these cases, the kinetic site of protonation may be $\mathrm{FeCN} .{ }^{8}$ The alkylation of $\mathrm{Ni}(0)$ carbonyl cyanides implicates the direct alkylation at nickel, not the cyanide ligands. ${ }^{9}$ In view of this background, it is not surprising that $\left[\mathrm{Fe}(\mathrm{CN})_{2}(\mathrm{CO})_{3}\right]^{2-}$ undergoes protonation at iron, not $\mathrm{FeCN}$, to give $\left[\mathrm{HFe}(\mathrm{CN})_{2}(\mathrm{CO})_{3}\right]^{-},\left[1 \mathrm{H}(\mathrm{CO})_{2}\right]^{-} \cdot{ }^{10}$ In the present paper, we examine the regiochemistry of reactions of $\left[\mathrm{Fe}(\mathrm{CN})_{2}(\mathrm{CO})_{3}\right]^{2-}$ with other electrophiles, including alkylating and acylating agents.

The hydride, $\left[1 \mathrm{H}(\mathrm{CO})_{2}\right]^{-}$, features the $\mathrm{HFe}(\mathrm{CN})_{2}(\mathrm{CO})$ center that is found at the active site for certain states of $[\mathrm{NiFe}]$-hydrogenases. ${ }^{3}$ Numerous structural and functional models for the [NiFe]-hydrogenase active site have been reported featuring ferrous cyanide complexes, ${ }^{11,12}$ but few studies have aimed at the hydride-containing Ni-C and Ni-R states. With this background in mind, the present paper describes the substitution chemistry of $\left[1 \mathrm{H}(\mathrm{CO})_{2}\right]^{-}$as a prelude to the construction of bimetallic models.

\section{Results and Discussion}

\section{Synthesis and Protonation of $\left[\mathrm{Fe}(\mathrm{CN})_{2}(\mathrm{CO})_{3}\right]^{2-}$}

The dianion $\left[\mathrm{Fe}(\mathrm{CN})_{2}(\mathrm{CO})_{3}\right]^{2-}$ arises in good yields by the photoreaction of solutions of either preformed $\left[\mathrm{Fe}(\mathrm{CN})(\mathrm{CO})_{4}\right]^{-}$or $\mathrm{Fe}(\mathrm{CO})_{5}$ and cyanide salts in $\mathrm{MeCN}$ solution. The conversion from $\mathrm{Fe}(\mathrm{CO})_{5}$ to $\left[\mathrm{Fe}(\mathrm{CN})_{2}(\mathrm{CO})_{3}\right]^{2-}$ can be effected in a one-pot process, although the second step is slow apparently due to self-extinction. An intense absorption band for [Fe $\left.(\mathrm{CN})_{2}(\mathrm{CO})_{3}\right]^{2-}$ occurs at $230 \mathrm{~nm}\left(\varepsilon=2 \times 10^{5} \mathrm{~cm}^{-1} \mathrm{M}^{-1}\right)$ and overlaps with the absorption band of the precursor $\left[\mathrm{Fe}(\mathrm{CN})(\mathrm{CO})_{4}\right]^{-}$at $210 \mathrm{~nm}\left(\varepsilon=8 \times 10 \mathrm{~cm}^{-1} \mathrm{M}^{-1}\right)$. Salts of $[\mathrm{Fe}$ $\left.(\mathrm{CN})_{2}(\mathrm{CO})_{3}\right]^{2-}$ can also be synthesized in water, but the conversion was slower and the purification less efficient. Usually $\left[\mathrm{Fe}(\mathrm{CN})_{2}(\mathrm{CO})_{3}\right]^{2-}$ was isolated as the $\left[\mathrm{K}(18 \text {-crown-6) }]^{+}\right.$ salt, because the product is easily separated from $\left[\mathrm{K}(18\right.$-crown-6)][Fe( $\left.\mathrm{CN})(\mathrm{CO})_{4}\right]$ and $[\mathrm{K}(18$ crown-6)] $\mathrm{CN}$ by a single reprecipitation. Other salts required multiple reprecipitation steps to fully purify the product.

The reaction of $\mathrm{Fe}(\mathrm{bda})(\mathrm{CO})_{3}$ and $\mathrm{Et}_{4} \mathrm{NCN}$ also gave $\mathrm{Et}_{4} \mathrm{~N}\left[\mathrm{Fe}(\mathrm{CN})(\mathrm{CO})_{4}\right]$ and $\left(\mathrm{Et}_{4} \mathrm{~N}\right)_{2}[\mathrm{Fe}$ $(\mathrm{CN})_{2}(\mathrm{CO})_{3}$ ] by displacement of bda (benzylideneacetone); however, the conversion proceeds to completion only upon addition of three equiv of $\mathrm{Et}_{4} \mathrm{NCN}$ due to the competing reaction between liberated bda and unreacted cyanide, and the organic products complicate workup.

Tetraethylammonium and $\left[\mathrm{K}(18 \text {-crown-6) }]^{+}\right.$salts of $\left[\mathrm{Fe}(\mathrm{CN})_{2}(\mathrm{CO})_{3}\right]^{2-}$ readily dissolve in deoxygenated water. The $v_{\mathrm{CO}}$ band of $\left[\mathrm{Fe}(\mathrm{CN})_{2}(\mathrm{CO})_{3}\right]^{2-}$ occurs $46 \mathrm{~cm}^{-1}$ higher in energy in aqueous solution $\left(1890 \mathrm{~cm}^{-1}\right)$ as opposed to MeCN solution $\left(1844 \mathrm{~cm}^{-1}\right)$. This type, which 
has been observed in other cyanocarbonyl complexes of iron, ${ }^{13,14}$ reflects the tendency of the cyanide ligands to engage in strong hydrogen bonds with hydroxylic solvents.

The electron-rich character of $\left[\mathrm{Fe}(\mathrm{CN})_{2}(\mathrm{CO})_{3}\right]^{2-}$ is indicated by the ease with which it can be oxidized. The cyclic voltammogram of $\left[\mathrm{K}(18 \text {-crown-6) }]_{2}\left[\mathrm{Fe}(\mathrm{CN})_{2}(\mathrm{CO})_{3}\right]\right.$ was found to consist of a single irreversible oxidation at $-600 \mathrm{mV}$ (vs. $\mathrm{Ag} / \mathrm{AgCl}, \mathrm{MeCN}$ solution). Treatment of a $\mathrm{MeCN}$ solution of $\left[\mathrm{Fe}(\mathrm{CN})_{2}(\mathrm{CO})_{3}\right]^{2-}$ with two equiv of $\mathrm{FcPF}_{6}\left(E_{1 / 2}=517 \mathrm{mV}\right.$ vs. $\left.\mathrm{Ag} / \mathrm{AgCl}\right)$ resulted in a color change to bright yellow, and IR analysis of the resulting solution showed numerous peaks in the range from $1800-2200 \mathrm{~cm}^{-1}$. The only product identifiable by ESI-MS was $\left[\mathrm{Fe}(\mathrm{CN})_{3}(\mathrm{CO})_{3}\right]^{-} .{ }^{13}$ Aerobic oxidation of $\left[\mathrm{Fe}(\mathrm{CN})_{2}(\mathrm{CO})_{3}\right]^{2-}$ is also complex, but IR spectra show the formation of both $\left[\mathrm{Fe}(\mathrm{CN})_{5}(\mathrm{CO})\right]^{3-}$ and trans- $\left[\mathrm{Fe}(\mathrm{CN})_{4}(\mathrm{CO})_{2}\right]^{2-} .{ }^{10}$

\section{Protonation of $\left[\mathrm{Fe}(\mathrm{CN})_{2}(\mathrm{CO})_{3}\right]^{2-}$}

Addition of one equiv of strong acids to solutions of $[\mathrm{K}(18 \text {-crown- } 6)]_{2}\left[\mathrm{Fe}(\mathrm{CN})_{2}(\mathrm{CO})_{3}\right]$ resulted in immediate and quantitative protonation of the iron complex. The resulting hydride [HFe $\left.(\mathrm{CN})_{2}(\mathrm{CO})_{3}\right]^{-}\left(\left[1 \mathrm{H}(\mathrm{CO})_{2}\right]^{-}\right)$, which is extremely air-sensitive in solution, was isolated as the salt $\left[\mathrm{K}\left(18\right.\right.$-crown-6)][1 $\left.\mathrm{H}(\mathrm{CO})_{2}\right]$. Colorless $\mathrm{CH}_{2} \mathrm{Cl}_{2}$ or $\mathrm{MeCN}$ solutions of this complex become bright yellow immediately upon exposure to air; however, the products could not be identified by IR spectroscopy or ESI-MS. Isolation of the hydride complex as an analytically-pure solid was complicated by the formation of salts (e.g. [K(18-crown-6)]Cl from $\mathrm{HCl}, \mathrm{Et}_{4} \mathrm{NOTs}$ from toluenesulfonic acid) with solubilities similar to that of the complex, but this problem was solved by using $\left.\left[\mathrm{H}\left(\mathrm{OEt}_{2}\right)_{2}\right]\left[\mathrm{BAr}{ }_{4}\right]\left(\mathrm{BAr}_{4} \mathrm{~F}_{4}=\mathrm{B}\left[\mathrm{C}_{6} \mathrm{H}_{2}-3,5-\mathrm{CF}_{3}\right)_{2}\right]_{4}^{-}\right)$, which allowed for the removal of the co-formed salts, which are soluble in ether.

The basicity of $\left[1 \mathrm{H}(\mathrm{CO})_{2}\right]^{-}$in $\mathrm{MeCN}$ solution was semi-quantified by monitoring changes in its IR spectrum. Protonation is fully effected using $\mathrm{NH}_{4} \mathrm{PF}_{6}\left(\mathrm{p} K_{\mathrm{a}}=16.46\right)$, and $\left[1 \mathrm{H}(\mathrm{CO})_{2}\right]^{-}$ can be fully deprotonated by one equiv of 2-aminoethanol $\left(\mathrm{p} K_{\mathrm{a}}=17.53\right)$, indicating a $\mathrm{p} K_{\mathrm{a}} \sim$ 17. All $\mathrm{p} K_{\mathrm{a}}$ values are for compounds dissolved in $\mathrm{MeCN}$ unless otherwise specified. Solutions of $\left[1 \mathrm{H}(\mathrm{CO})_{2}\right]^{-}$in $\mathrm{CD}_{2} \mathrm{Cl}_{2}$ undergo rapid $\mathrm{H} / \mathrm{D}$ exchange with $\mathrm{D}_{2} \mathrm{O}$ to give the corresponding deuteride complex, $\left[\mathrm{DFe}(\mathrm{CN})_{2}(\mathrm{CO})_{3}\right]^{-}$, while such solutions of $\left[1 \mathrm{H}(\mathrm{CO})_{2}\right]^{-}$do not undergo $\mathrm{H} / \mathrm{D}$ exchange with $\mathrm{D}_{2}$.

\section{Derivatives of $\left[\mathrm{HFe}(\mathrm{CN})_{2}(\mathrm{CO})_{3}\right]^{-}$}

The ferrous hydride $\left[1 \mathrm{H}(\mathrm{CO})_{2}\right]^{-}$exhibits enhanced electrophilicity relative to its dianionic precursor, which resists substitution reactions. Treatment of $\left[\mathrm{K}\left(18\right.\right.$-crown-6)][1 $\left.\mathrm{H}(\mathrm{CO})_{2}\right]$ with tertiary phosphines or phosphites in $\mathrm{MeCN}$ solution resulted in rapid evolution of $\mathrm{CO}$ and formation of $\left[\mathrm{K}\left(18\right.\right.$-crown-6)][HFe $\left.(\mathrm{CN})_{2}(\mathrm{CO})_{2} \mathrm{~L}\right]\left(\mathrm{L}=\mathrm{P}(\mathrm{OPh})_{3}\right.$ and $\left.\mathrm{PPh}_{3}\right),[\mathrm{K}(18$-crown-6)] $[1 \mathrm{H}(\mathrm{CO}) \mathrm{L}]$. These complexes exhibit two $v_{\mathrm{CO}}$ bands, consistent with cis carbonyl ligands. ${ }^{1} \mathrm{H}$ - and ${ }^{31} \mathrm{P}-\mathrm{NMR}$ spectra show multiple stable isomers as also observed for $[\mathbf{1 H}$ $\left.(\mathrm{CO})_{2}\right]^{-}$. The reaction of $\left[1 \mathrm{H}(\mathrm{CO})_{2}\right]^{-}$with phosphorus donor ligands is an equilibrium process. Upon placing a MeCN solution of $\left[\mathrm{K}\left(18\right.\right.$-crown-6)][1 $\left.\mathrm{H}(\mathrm{CO})\left(\mathrm{PPh}_{3}\right)\right]$ under an atmosphere of $\mathrm{CO}$, a mixture of $\left[1 \mathrm{H}(\mathrm{CO})_{2}\right]^{-},\left[1 \mathrm{H}(\mathrm{CO})\left(\mathrm{PPh}_{3}\right)\right]^{-}$, and $\mathrm{PPh}_{3}$ was observed by ${ }^{1} \mathrm{H}-$ and ${ }^{31} \mathrm{P}-\mathrm{NMR}$ spectroscopy. Purging these solution with $\mathrm{N}_{2}$ gave $\left[1 \mathrm{H}(\mathrm{CO})\left(\mathrm{PPh}_{3}\right)\right]^{-}$. The $\mathrm{P}(\mathrm{OPh})_{3}$ complex formed analogously. Treatment of $\left[1 \mathrm{H}(\mathrm{CO})\left\{\mathrm{P}(\mathrm{OPh})_{3}\right\}\right]^{-}$with one equiv of $\mathrm{PPh}_{3}$ gave $[1 \mathrm{H}(\mathrm{CO})$ $\left.\left(\mathrm{PPh}_{3}\right)\right]^{-}$. The phosphine ligand in $\mathrm{PPN}\left[\mathrm{HFe}(\mathrm{CO})_{3}\left(\mathrm{PPh}_{3}\right)\right]$ is known to be reversibly displaceable by $\mathrm{CO} .{ }^{15}$

The introduction of the phosphorus ligand significantly affects the acidity of the hydride. Whereas the $\mathrm{p} K_{\mathrm{a}}$ of $\left[1 \mathrm{H}(\mathrm{CO})_{2}\right]^{-}$is $\sim 17$ in $\mathrm{MeCN},[1 \mathrm{H}(\mathrm{CO}) \mathrm{L}]^{-}\left(\mathrm{L}=\mathrm{PPh}_{3}, \mathrm{P}(\mathrm{OPh})_{3}\right)$ resisted deprotonation by tetramethylguanidine $\left(\mathrm{p} K_{\mathrm{a}}=23.3\right.$ in $\left.\mathrm{MeCN}\right)$. Such decreases in acidity are precedented in the case of $\mathrm{HCo}(\mathrm{CO})_{4-\mathrm{x}}\left(\mathrm{PPh}_{3}\right)_{\mathrm{x}}(\mathrm{x}=1,0)$ where the $K_{\mathrm{a}}$ of the phosphine adduct 
was $10^{7}$ greater for the tetracarbonyl. ${ }^{16}$ The $\mathrm{P}(\mathrm{OPh})_{3}$ - and $\mathrm{PPh}_{3}$-substituted complexes do not undergo further substitution by these phosphorus ligands even in refluxing solvent.

In contrast to the situation for monophosphines and phosphites, one equiv of the chelating diphosphine cis- $\mathrm{Ph}_{2} \mathrm{PCH}=\mathrm{CHPPh}_{2}(\mathrm{dppv})$ was found to displace two $\mathrm{CO}$ ligands from $[\mathbf{1 H}$ $\left.(\mathrm{CO})_{2}\right]^{-}$, rapidly generating $\left[\mathrm{HFe}(\mathrm{CN})_{2}(\mathrm{CO})(\mathrm{dppv})\right]^{-}\left([1 \mathrm{H}(\mathrm{dppv})]^{-}\right)$. The solution IR spectrum of $\left[\mathrm{K}\left(18\right.\right.$-crown-6)][1H(dppv)] in MeCN consisted of a single $v_{\mathrm{CO}}$ band at $1936 \mathrm{~cm}^{-1}$ and two $v_{\mathrm{CN}}$ bands at 2087 and $2080 \mathrm{~cm}^{-1}$. The IR spectrum of $[1 \mathrm{H}(\mathrm{dppv})]^{-}$also closely resembles that of $\left[\mathrm{CpFe}(\mathrm{CN})_{2}(\mathrm{CO})\right]^{-} .{ }^{17}$ Unlike the aforementioned cases of $\left[1 \mathrm{H}(\mathrm{CO})\left(\mathrm{PR}_{3}\right)\right](\mathrm{R}=\mathrm{Ph}$, $\mathrm{OPh})$, solutions of $[1 \mathrm{H}(\mathrm{dppv})]^{-}$were unaffected by $\mathrm{CO}$. Upon standing in solution, $[1 \mathrm{H}$ (dppv) $]^{-}$was found to convert to a mixture containing $>90 \%$ of a single isomer over the course of hours at room temperature, although the IR spectra of the isomers were apparently indistinguishable. Thus, seconds after adding dppv to a $\mathrm{CD}_{3} \mathrm{CN}$ solution of $\left[1 \mathrm{H}(\mathrm{CO})_{2}\right]^{-}$, the ${ }^{1} \mathrm{H}$ NMR spectrum exhibited a triplet and two doublets of doublets (see Supplementary Information). Within minutes, these signals diminished, concomitant with the appearance of a new triplet $\left(\delta-8.64 ;{ }^{2} J_{\mathrm{P}-\mathrm{H}}=58 \mathrm{~Hz}\right)$. A singlet $(\delta 103.7)$ in the ${ }^{31} \mathrm{P}-\mathrm{NMR}$ spectrum indicated of the unique $C_{\mathrm{s}}$-symmetrical isomer. This thermodynamic product can be described as having the cyanides and dppv in the equatorial plane with the hydride and $\mathrm{CO}$ along the axis.

We also attemped the substitution of $\mathrm{CO}$ by sulfur ligands, since the coordination sphere about $\mathrm{Fe}$ in the $[\mathrm{NiFe}]$-hydrogenases is $\mathrm{FeH}(\mathrm{CN})_{2}(\mathrm{CO})(\mathrm{SR})_{2}$. The hydride $\left[\mathbf{1 H}(\mathrm{CO})_{2}\right]^{-}$was deprotonated by NaSPh. We observed no reaction between $[1 \mathrm{H}(\mathrm{CO}) \mathrm{L}]^{-}\left(\mathrm{L}=\mathrm{PPh}_{3}, \mathrm{P}(\mathrm{OPh})_{3}\right)$ and $\mathrm{Me}_{2} \mathrm{~S}, \mathrm{NaS}_{2} \mathrm{CNEt}_{2}, \mathrm{NaSPh}$, and $\mathrm{MeSCH}_{2} \mathrm{CH}_{2} \mathrm{SMe}$. No reaction was also observed between $\left[1 \mathrm{H}(\mathrm{CO})_{2}\right]^{-}$and olefins such as styrene or norbornene.

\section{Kinetics of Carbonyl Substitution}

The rate of substitution of $\mathrm{CO}$ in $\left[1 \mathrm{H}(\mathrm{CO})_{2}\right]^{-}$by $\mathrm{P}(\mathrm{OPh})_{3}$ was examined under conditions of excess phosphite (Figure 1). Upon varying the amount of $\mathrm{P}(\mathrm{OPh})_{3}$ from 10 to 40 equiv, the rate increased by a factor of 4 , indicating a first-order dependence upon the incoming ligand; the rate was also first-order in $\left[1 \mathrm{H}(\mathrm{CO})_{2}\right]^{-}$, consistent with a second-order rate law. Rates were evaluated over a temperature range of 22 to $-29^{\circ} \mathrm{C}$ (see Supplementary Information) to give the following activation parameters: $\Delta H^{\ddagger}=51.6 \mathrm{~kJ} \mathrm{~mol}^{-1}$ and $\Delta S^{\ddagger}=-83 \mathrm{~J} \mathrm{~K}^{-1} \mathrm{~mol}^{-1}$.

\section{$\left[\mathrm{HFe}(\mathrm{CN})_{3}(\mathrm{CO})_{2}\right]^{2-}$}

Substitution of $\mathrm{CO}$ in $\left[1 \mathrm{H}(\mathrm{CO})_{2}\right]^{-}$is limited by the Brønsted basicity of the attacking ligand since highly basic reagents deprotonate the complex. Consistent with this pattern, treatment of $\left[\mathrm{K}\left(18\right.\right.$-crown-6)][1 $\left.\mathrm{H}(\mathrm{CO})_{2}\right]$ with $\mathrm{Et}_{4} \mathrm{NCN}$ resulted in rapid deprotonation of the hydride to cleanly regenerate $\left[\mathrm{Fe}(\mathrm{CN})_{2}(\mathrm{CO})_{3}\right]^{2-}$, as indicated by in situ IR spectroscopy. The facility of the deprotonation is consistent with the low acidity of $\mathrm{HCN}$, with a $\mathrm{p} K_{\mathrm{a}}=18.1 .{ }^{18} \mathrm{An}$ indirect route to the tricyanide was therefore undertaken, bearing in mind the decreased acidity of $[1 \mathrm{H}$ (CO) $\left.\left(\mathrm{PPh}_{3}\right)\right]^{-}$and the lability of $\mathrm{PPh}_{3}$. Treatment of a MeCN solution of $\left[1 \mathrm{H}(\mathrm{CO})\left(\mathrm{PPh}_{3}\right)\right]^{-}$ with one equiv $\mathrm{Et}_{4} \mathrm{NCN}$ was found to rapidly generate the targeted hydrido tricyanide complex $\left[\mathrm{HFe}(\mathrm{CN})_{3}(\mathrm{CO})_{2}\right]^{2-}\left([\mathbf{1 H}(\mathrm{CN})(\mathrm{CO})]^{2-}\right)$ concomitant with displacement of $\mathrm{PPh}_{3}$. The analogous phosphite complex $\left[1 \mathrm{H}(\mathrm{CO})\left\{\mathrm{P}(\mathrm{OPh})_{3}\right\}\right]^{-}$was found to react similarly. Excess cyanide does not result in further substitution. The IR spectrum of $[1 \mathrm{H}(\mathrm{CN})(\mathrm{CO})]^{2-}$ showed the expected two-band $v_{\mathrm{CO}}$ pattern at approximately $20 \mathrm{~cm}^{-1}$ lower energy than for $[1 \mathrm{H}(\mathrm{CO})$ $\left.\left(\mathrm{PPh}_{3}\right)\right]^{-}$. The ${ }^{1} \mathrm{H}-\mathrm{NMR}$ spectrum showed the presence of three hydride signals, reflecting the presence of the three possible isomers in a ratio of $\sim 10: 6: 0.5$. The isomer ratio in $\mathrm{CD}_{3} \mathrm{CN}$ solution was found to be unchanged upon sitting for days at room temperature. 


\section{Protonation of Ferrous Hydride Complexes}

The basicity of the new iron hydrides is highly dependent upon the coligands, as expected. ${ }^{19}$ Treatment of a MeCN solution of $[1 \mathrm{H}(\mathrm{dppv})]^{-}$with one equiv of $\left[\mathrm{H}\left(\mathrm{OEt}_{2}\right)_{2}\right] \mathrm{BAr}_{4} \mathrm{~F}_{4}$ resulted in the slow crystallization of a yellow product along with the evolution of $\mathrm{H}_{2}\left({ }^{1} \mathrm{H}-\mathrm{NMR}\right.$ spectrum: 84.56). The IR spectrum of the precipitated yellow solid exhibited a $v_{\mathrm{CO}}$ band $1993 \mathrm{~cm}^{-1}$ (vs. $1934 \mathrm{~cm}^{-1}$ for $\left.[\mathbf{1 H}(\mathrm{dppv})]^{-}\right)$. Elemental analysis and NMR measurements indicated that this reaction produced $\mathrm{Fe}(\mathrm{CN})_{2}(\mathrm{NCMe})(\mathrm{CO})(\mathrm{dppv}), \mathbf{1}(\mathrm{NCMe})(\mathrm{dppv})$. This species is formed as a single isomer as evidenced by a singlet at $\delta 83.7$ in the ${ }^{31} \mathrm{P}$ NMR spectrum. Protonation of $\mathrm{CH}_{2} \mathrm{Cl}_{2}$ solutions of $[1 \mathrm{H}(\mathrm{dppv})]^{-}$with $\left[\mathrm{H}\left(\mathrm{OEt}_{2}\right)\right]\left[\mathrm{BArF}_{4}\right]$ resulted in the release of $\mathrm{H}_{2}$. The IR spectrum of this solution showed one $v_{\mathrm{CO}}$ peak at $2003 \mathrm{~cm}^{-1}$ and a broadened $v_{\mathrm{CN}}$ band. The ${ }^{31} \mathrm{P}-\mathrm{NMR}$ spectrum showed a singlet. Upon dissolving this product into $\mathrm{MeCN}$, the $v_{\mathrm{CO}}$ band shifted to $1993 \mathrm{~cm}^{-1}$, and the $v_{\mathrm{CN}}$ sharpened. We hypothesize that protonation generates a labile $\mathrm{H}_{2}$ ligand that is displaced by $\mathrm{FeCN}$ on another molecule of $\mathrm{Fe}(\mathrm{CN})_{2}(\mathrm{CO})(\mathrm{dppv})$ to give the polymer $\left[\mathrm{Fe}(\mathrm{CN})_{2}(\mathrm{CO})(\mathrm{dppv})\right]_{\mathrm{n}}$. In $\mathrm{MeCN}$ solution, this species depolymerizes to give $\mathbf{1}(\mathrm{NCMe})(\mathrm{dppv})$.

Similarly, protonation of the tricyanide $\left[\mathrm{K}(18 \text {-crown-6) }]_{2}[1 \mathrm{H}(\mathrm{CN})(\mathrm{CO})]\right.$ with an $\mathrm{MeCN}$ solution of $\mathrm{HCl}$ resulted in the immediate release of $\mathrm{H}_{2}$ and the formation of [K(18-crown-6)] $\left[\mathrm{Fe}(\mathrm{CN})_{3}(\mathrm{NCMe})(\mathrm{CO})_{2}\right],[\mathrm{K}(18$-crown-6)][1(CN)(NCMe $)(\mathrm{CO})]$. The formation of $[\mathrm{K}(18-$ crown-6)][1(CN)(NCMe)(CO)] is evidenced by an approximately $60 \mathrm{~cm}^{-1}$ shift to higher energy for $v_{\mathrm{CO}}$, similar to the shift seen upon formation of $\mathbf{1}(\mathrm{NCMe})(\mathrm{dppv})$ from $[\mathrm{K}(18-$ crown-6)][1 $1 \mathrm{H}(\mathrm{dppv})]$. Liaw and coworkers had previously obtained $[1(\mathrm{CN})(\mathrm{NCMe})(\mathrm{CO})]^{-}$in low yield from the reactions of $\mathrm{PPN}\left[\mathrm{FeBr}(\mathrm{CN})_{2}(\mathrm{CO})_{3}\right]$ as well as $(\mathrm{PPN})_{2}\left[\mathrm{FeBr}(\mathrm{CN})_{3}(\mathrm{CO})_{2}\right]$. ${ }^{20}$ No reaction between $[\mathbf{1}(\mathrm{CN})(\mathrm{NCMe})(\mathrm{CO})]^{-}$and cyanide was observed.

\section{Structural Studies of Ferrous Cyanide Complexes}

The structure of [K(18-crown-6)][1 $\mathrm{H}(\mathrm{dppv})]$, determined by single-crystal X-ray diffraction (Figure 2), is consistent with the IR and NMR data. The hydride was located in the difference map with a Fe-H distance of 1.51(6) $\AA$. The cyanide and carbonyl ligands were distinguished by their $\mathrm{Fe}-\mathrm{C}$ bond lengths (Table 1$)$. The $[\mathrm{K}(18 \text {-crown- } 6)]^{+}$cation lies in close proximity to the cis-cyanide ligands; the resulting interaction is such that the potassium ion is removed from the center of the crown ether toward the cyanides.

The complex $\mathbf{1}(\mathrm{NCMe})(\mathrm{dppv})$ was also characterized by single crystal X-ray diffraction (see Supplementary Information). The molecular structure is consistent with retention of stereochemistry of the precursor $[1 \mathrm{H}(\mathrm{dppv})]^{-}$upon protonolysis.

Crystallographic analysis of the tricyanide $\left[\mathrm{K}(18 \text {-crown-6) }]_{2}[\mathbf{1 H}(\mathrm{CN})(\mathrm{CO})]\right.$ (Figure 3) failed to locate the hydride ligand; however, an unoccupied coordination site is indicated an otherwise five-coordinate square pyramidal complex. The presence of a pair of [K(18-crown-6) ${ }^{+}$ counter-cations and a non-coordinating acetonitrile solvate imply the presence of a hydride ligand. The three cyanide ligands reside in the equatorial plane with one carbonyl: the hydride and the remaining carbonyl occupy axial positions. The potassium atoms in the $[\mathrm{K}(18-$ crown-6) $]^{+}$cations are located within close proximity to the trans cyanide ligands.

\section{Alkylation and Acylation of $\left[\mathrm{Fe}(\mathrm{CN})_{2}(\mathrm{CO})_{3}\right]^{2-}$}

To test the scope of its nucleophilic reactivity, $\left[\mathrm{Fe}(\mathrm{CN})_{2}(\mathrm{CO})_{3}\right]^{2-}$ was treated with a selection of organic electrophiles. Combining a MeCN solution of $\left[\mathrm{K}(18 \text {-crown-6) }]_{2}\left[\mathrm{Fe}(\mathrm{CN})_{2}(\mathrm{CO})_{3}\right]\right.$ with one equiv of MeOTf resulted in a rapid reaction, as indicated by changes in the IR spectra. The IR spectrum of the resulting solution resembled that for $\left[\mathrm{K}(18 \text {-crown-6)][1H(CO) })_{2}\right]$ (Figure 4), consistent with alkylation at Fe, i.e. the formation of [K(18-crown-6)][MeFe $\left.(\mathrm{CN})_{2}(\mathrm{CO})_{3}\right]$, $\left[\mathrm{K}(18 \text {-crown-6)][1Me(CO) })_{2}\right]$. The formula was confirmed by ESI-MS of the 
reaction mixture. At $-40{ }^{\circ} \mathrm{C}$, solutions of this alkylated derivative are stable for hours. The same IR spectra were obtained when the reaction was performed using $\mathrm{MeI}$ or $\left[\mathrm{Me}_{3} \mathrm{O}\right] \mathrm{BF} 4$ as the methylating agents; in each case, however, the product decomposed upon attempted isolation.

For reference, we examined the methylation of $\mathrm{K}\left[\mathrm{Fe}(\mathrm{CN})(\mathrm{CO})_{4}\right]$ with $\mathrm{MeOTf}$ in $\mathrm{MeCN}$ solution. The exclusive product, identified by IR spectroscopy, was $\mathrm{Fe}(\mathrm{CO})_{4}(\mathrm{CNMe}) .{ }^{21} \mathrm{We}$ had earlier reported that the protonation of the monocyanide $\left[\mathrm{Fe}(\mathrm{CN})(\mathrm{CO})_{4}\right]^{-}$reacts with $\mathrm{HCl}$ to give a mixture of $\mathrm{Fe}(\mathrm{CO})_{4}(\mathrm{CNH})$ (major) and $\mathrm{HFe}(\mathrm{CN})(\mathrm{CO})_{4}$ (minor). ${ }^{10}$ The methylation result suggests that protonation may also occur at $\mathrm{FeCN}$, the likely kinetic site, followed by slower rearrangement to the hydride tautomer. We have observed this pattern of $N$ - followed by $\mathrm{Fe}$-protonation in studies of $\left[\mathrm{Fe}_{2}\left(\mathrm{~S}_{2} \mathrm{C}_{2} \mathrm{H}_{4}\right)(\mathrm{CN})_{2}(\mathrm{CO})_{4}\right]^{2-}$.

The MeCN solution of $\left[1 \mathrm{Me}(\mathrm{CO})_{2}\right]^{-}$, which is unstable, was found to react with dppv to give a robust derivative. Upon addition of dppv to an $\mathrm{MeCN}$ solution of the complex, gas evolution was observed. In the IR spectrum, a band at $1937 \mathrm{~cm}^{-1}$ appeared as seen for the hydride [K (18-crown-6)][1H(dppv)] and a band of medium intensity was observed at $1600 \mathrm{~cm}^{-1}$, consistent with $v_{\mathrm{C}=\mathrm{O}}$ of an acetyl complex. The ${ }^{1} \mathrm{H}-\mathrm{NMR}$ spectrum exhibited a singlet for an acetyl group at $\delta 2.60$, and the ESI-mass spectrum confirmed that the complex was indeed the acetyl, $[\mathbf{1 A c}(\mathrm{dppv})]^{-}$. Cardaci and coworkers observed similar spectral features in $\mathrm{Fe}(\mathrm{COMe})$ $(\mathrm{CN})(\mathrm{CO})_{2}\left(\mathrm{PMe}_{3}\right)_{2}$, which they prepared from cyanation of $\left[\mathrm{Fe}(\mathrm{Me})(\mathrm{CO})_{3}\left(\mathrm{PMe}_{3}\right)_{2}\right]^{+} .{ }^{22}$ Acetyl complex [1 Ac(dppv) $]^{-}$exhibited no tendency to decarbonylate-even in refluxing $\mathrm{MeCN}$.

Whereas $\left[\mathrm{Fe}(\mathrm{CN})_{2}(\mathrm{CO})_{3}\right]^{2-}$ was found to protonate and alkylate at the metal, acid chlorides ( $\mathrm{MeCOCl}, \mathrm{PhCOCl})$ gave $N$-acyl isocyanide complexes $\left[\mathrm{Fe}(\mathrm{CN})(\mathrm{CO})_{3}(\mathrm{CNCOR})\right]^{-}(\mathrm{R}=\mathrm{Me}$, $\mathrm{Ph})$, which were readily obtained in analytical purity. As expected, ${ }^{23}$ the IR spectra in the $v_{\mathrm{CO}}$ region are similar for $\left[\mathrm{Fe}(\mathrm{CN})(\mathrm{CO})_{3}(\mathrm{CNCOR})\right]^{-}$and $\left[\mathrm{Fe}(\mathrm{CN})(\mathrm{CO})_{4}\right]^{-}$(see Supplementary Information). The acyl derivatives were characterized by a new $v_{\mathrm{CO}}$ band at $\sim 1660 \mathrm{~cm}^{-1}$ for the $\mathrm{RC}(\mathrm{O}) \mathrm{NC}$ ligand.

\section{Summary}

In this work, we have developed the $\mathrm{H}-\mathrm{CN}-\mathrm{CO}-\mathrm{Fe}$ system. Two members of the series are now well characterized, $\left[\mathrm{HFe}(\mathrm{CN})_{3}(\mathrm{CO})_{2}\right]^{2-}$ and $\left[\mathrm{HFe}(\mathrm{CN})_{2}(\mathrm{CO})_{3}\right]^{-}$. The species $\left[\mathrm{HFe}(\mathrm{CN})_{5}\right]^{4-}$ and $\left[\mathrm{HFe}(\mathrm{CN})_{4}(\mathrm{CO})\right]^{3-}$ remain unknown, although related hydridocyanocobaltates are known. ${ }^{24}$ This series of complexes complements the ferrous cyanide carbonyl complexes of the type $\left[\mathrm{Fe}(\mathrm{CN})_{\mathrm{X}}(\mathrm{CO})_{6-\mathrm{x}}\right]^{(-2-x)}(x=3,4,5) \cdot{ }^{13,14,25}$

This compound [K(18-crown-6)][1 $\mathrm{H}(\mathrm{dppv})]$ is a rare example of a hydrido iron carbonyl cyanide. Another example is the bimetallic species $\mathrm{Fe}_{2}\left(\mathrm{~S}_{2} \mathrm{C}_{3} \mathrm{H}_{6}\right)(\mu-\mathrm{H})(\mathrm{CN})(\mathrm{CO})_{4}\left(\mathrm{PMe}_{3}\right){ }^{26}$ Spectroscopically and structurally, $[1 \mathrm{H}(\mathrm{dppv})]^{-}$is a reasonable structural model for the $\mathrm{Fe}$ site of the [NiFe]-hydrogenases (Figure 5). The similarity extends to the IR spectra in the $v_{\mathrm{CO}}$ and $v_{\mathrm{CN}}$ regions. ${ }^{27}$

Whereas $\left[\mathrm{Fe}(\mathrm{CN})_{2}(\mathrm{CO})_{3}\right]^{2-}$ resists substitution, its protonated derivative $\left[1 \mathrm{H}(\mathrm{CO})_{2}\right]^{-}$is readily monosubstituted by soft ligands such as phosphines, phosphites, and cyanide. Substitution by $\mathrm{P}(\mathrm{OPh})_{3}$ was examined in some detail, and the negative activation entropy and bimolecular rate law point to an associative mechanism. For the related reaction of a variety of metal hydride complexes (e.g. $\left.\left[\mathrm{HFe}(\mathrm{CO})_{4}\left(\mathrm{PPh}_{3}\right)\right]^{+}, \mathrm{HCo}(\mathrm{CO})_{4}\right)$, Pearson has suggested that the nucleophile induces migration of the hydride to a carbonyl ligand followed by rapid deinsertion with loss of $\mathrm{CO}$ (Scheme 2). ${ }^{28} \mathrm{~A}$ similar mechanism is expected for the substitution of chelating diphosphines. Thus, a stable acetyl species forms upon addition of dppv to $\left[1 \mathrm{Me}(\mathrm{CO})_{2}\right]^{-}$, 
whereas the corresponding formyl species is apparently less stable, resulting in decarbonylation to give the hydride complex.

The influence of the coligands on the basicity of the Fe vs the $\mathrm{CN}$ centers is relevant to understanding the regiochemistry of protonation reactions. Angelici has assessed the basicity of series of $\mathrm{Fe}(\mathrm{CO})_{3}$ (phosphine $)_{2}$ and $\mathrm{Fe}(\mathrm{CO})_{3}$ (diphosphine) complexes and has shown that the enthalpies of protonation correlates with $\mathrm{p} K_{\mathrm{a}} \cdot{ }^{29}$ For example, $\mathrm{Fe}(\mathrm{CO})_{3}\left(\mathrm{PMe}_{3}\right)_{2}$, has a heat of protonation $\left(-\Delta \mathrm{H}_{\mathrm{HM}}\right)$ of $23.3 \mathrm{kcal} / \mathrm{mol}$. We estimate that $\left[\mathrm{Fe}(\mathrm{CO})_{3}\left(\mathrm{PMe}_{3}\right)_{2}\right]^{+}$has a $\mathrm{p} K_{\mathrm{a}}(\mathrm{MeCN})$ of 16.6 (see Supplementary Information). For comparison, $\left[\mathbf{1 H}(\mathrm{CO})_{2}\right]^{-}$has $\mathrm{p} K_{\mathrm{a}}(\mathrm{MeCN})$ of about 17. Similar comparability of $\mathrm{p} K_{\mathrm{a}}$ values has been observed in dinuclear complexes, as well, with $\left[\mathrm{Fe}_{2}\left(\mathrm{~S}_{2} \mathrm{C}_{3} \mathrm{H}_{6}\right)(\mu-\mathrm{H})(\mathrm{CO})_{4}\left(\mathrm{PMe}_{3}\right)_{2}\right]^{+}$and $\left[\mathrm{Fe}_{2}\left(\mathrm{~S}_{2} \mathrm{C}_{3} \mathrm{H}_{6}\right)(\mu-\mathrm{H})\right.$ $\left.(\mathrm{CN})_{2}(\mathrm{CO})_{4}\right]^{-}$, both having $\mathrm{p} K_{\mathrm{a}}$ values between 10.4 and 11.3. ${ }^{8,26}$

Neutral complexes of the type $\mathrm{Fe}(\mathrm{CO})_{3} \mathrm{~L}_{2}\left(\mathrm{~L}=\mathrm{P}(\mathrm{OPh})_{3}, \mathrm{PPh}_{3}, \mathrm{PPh}_{2} \mathrm{Me}, \mathrm{P}\left(\mathrm{NMe}_{2}\right)_{3}\right)$ undergo reversible one-electron oxidation in a range from 0.73 to $0.19 \mathrm{~V}$ vs $\mathrm{Ag} / \mathrm{AgCl}$, and the diphosphine complex $\mathrm{Fe}(\mathrm{CO})_{3}(\mathrm{dppe})$ oxidizes at $0.15 \mathrm{~V}$ vs $\mathrm{Ag} / \mathrm{AgCl}$. The products in these cases are the corresponding five-coordinate (17e) derivatives. ${ }^{30}$ These neutral $\mathrm{Fe}(\mathrm{CO})_{3} \mathrm{~L}_{2}$ complexes are all much more difficult to oxidize than $\left[\mathrm{Fe}(\mathrm{CN})_{2}(\mathrm{CO})_{3}\right]^{2-}(-600 \mathrm{mV}$, irreversible).

Protonation of metal cyanides most often occurs at cyanide to give complexes containing the $\mathrm{CNH}$ ligand. ${ }^{5}$ Depending on their degree of substitution, the cyanocarbonyls of $\mathrm{Fe}(0)$ protonate either mainly at cyanide or at Fe to give a hydride complex. The regiochemistry of protonation in such complexes depends on the basicity of the respective sites. For example, the low temperature $\left(-30{ }^{\circ} \mathrm{C}\right)$ protonation of $\left[\mathrm{Fe}(\mathrm{CN})(\mathrm{CO})_{4}\right]^{-}$results in the formation of a mixture of mainly $\mathrm{Fe}(\mathrm{CO})_{4}(\mathrm{CNH})$ as well as $\mathrm{HFe}(\mathrm{CN})(\mathrm{CO})_{4}$ prior to decomposition by loss of $\mathrm{HCN} .{ }^{10}$ Consistent with this result, methylation on the monocyanide gives $\mathrm{Fe}(\mathrm{CO})_{4}(\mathrm{CNMe})$. The dicyanide, $\left[\mathrm{Fe}(\mathrm{CN})_{2}(\mathrm{CO})_{3}\right]^{2-}$, is significantly more basic at $\mathrm{Fe}$, and no $\mathrm{CNH}$ and $\mathrm{CNMe}$ species are observed. The substitution of $\mathrm{CO}$ for $\mathrm{CN}^{-}$, in this case, has the effect of elevating the nucleophilicity of the $\mathrm{Fe}(0)$ center above that of the $\mathrm{FeCN}$ centers.

Whereas the coligands slightly affect the acidity of the $\mathrm{MCN} H$ center, ${ }^{31}$ the acidity of the $\mathrm{M} H$ is highly sensitive to the nature of the ligand set. This effect can be seen when comparing the difference in heats of protonation $\left(\Delta \Delta \mathrm{H}_{\mathrm{H}+}\right)$ of complexes of the type $\mathrm{CpRu}\left(\mathrm{PR}_{3}\right)_{2}(\mathrm{CN})$ to those of $\mathrm{Fe}(\mathrm{CO})_{3}\left(\mathrm{PR}_{3}\right)_{2}$. In the first case, only protonation at cyanide occurs, and $\Delta \Delta \mathrm{H}_{\mathrm{H}}$ increases by only $1.9 \mathrm{kcal} / \mathrm{mol}$ upon substituting $\mathrm{PPh}_{3}$ for $\mathrm{PMe}_{3}{ }^{32}$ In the latter case, protonation at Fe occurs, and $\Delta \Delta \mathrm{H}_{\mathrm{H}+}$ increases by $9.2 \mathrm{kcal} / \mathrm{mol}$ upon substituting $\mathrm{PPh}_{3}$ for $\mathrm{PMe}_{3}{ }^{33}$

Protonation of the dicyanoferrous hydrides described in this work did not afford isolable complexes of $\mathrm{H}_{2}$. Protonation of the hydride in $[1 \mathrm{H}(\mathrm{CO}) \mathrm{L}]^{-}$would generate charge-neutral products, whereas most stable $\mathrm{H}_{2}$ complexes are cations ${ }^{34}$ Consisting of six potentially anionic ligands - four thiolates and two cyanides, the active site of the [NiFe]-hydrogenases (and the $\mathrm{H}_{2}$ adducts) would also be expected to be anionic. The instability of such adducts may be consistent with the high efficiency of [NiFe]-hydrogenase $\left(\mathrm{H}_{2}\right.$ uptake: $1500 \mu \mathrm{mol} \mathrm{H}_{2} \mathrm{~min}^{-1}$ / mg protein $\left.{ }^{-1}\right){ }^{35}$ It is known that $\mathrm{H}_{2}$ formation by membrane-bound [NiFe]-hydrogenases in Ralstonia species is inhibited by $\mathrm{H}_{2} \cdot{ }^{36}$

\section{Experimental Section}

Reactions were conducted as previously described using standard Schlenk techniques or in an inert atmosphere glovebox under dinitrogen. Solvents were dried via filtration through two 1 m columns of alumina. $\mathrm{CD}_{3} \mathrm{CN}$ and $\mathrm{CD}_{2} \mathrm{Cl}_{2}$ were purchased from Cambridge Isotopes and were dried with and distilled from $\mathrm{CaH}_{2}$. $\left[\mathrm{H}\left(\mathrm{OEt}_{2}\right)_{2}\right] \mathrm{BAr}_{4}{ }_{4}$ was prepared by literature methods. ${ }^{37}$ Other reagents were purchased and used as received. 


\section{$[\mathrm{K}(18-\mathrm{crown}-6)]_{2}\left[\mathrm{Fe}(\mathrm{CN})_{2}(\mathrm{CO})_{3}\right]$}

A slurry of $0.25 \mathrm{~g}(3.8 \mathrm{mmol})$ of $\mathrm{KCN}$ in $\mathrm{MeCN}$ was treated with $1.10 \mathrm{~g}(4.16 \mathrm{mmol})$ of 18 crown- 6 and stirred until the solids dissolved. $\mathrm{Fe}(\mathrm{CO})_{5}(0.25 \mathrm{~mL}, 1.9 \mathrm{mmol})$ was added to the solution, and the pale yellow reaction mixture was photolyzed. Photolysis was continued until no more significant changes were observed in the IR spectrum and no more gas evolution was observed. The reaction mixture was filtered to give a clear, very pale yellow solution. The product was precipitated by concentrating the reaction solution to a volume of about $10 \mathrm{~mL}$ and adding about $60 \mathrm{~mL}$ of EtOAc. The solid was isolated by filtration and washed with 20

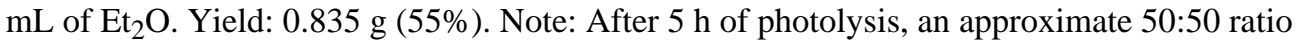
of $\left[\mathrm{Fe}(\mathrm{CN})_{2}(\mathrm{CO})_{3}\right]^{2-}:\left[\mathrm{Fe}(\mathrm{CN})(\mathrm{CO})_{4}\right]^{-}$was observed. Continuing the photolysis for another $17 \mathrm{~h}$ resulted in a negligible increase in that ratio. Using $\mathrm{MeOH}$ as the reaction solvent resulted in the formation of only $\left[\mathrm{Fe}(\mathrm{CN})(\mathrm{CO})_{4}\right]^{-}$; no dicyanide was observed, possibly due to overlap of the absorption bands of $\left[\mathrm{Fe}(\mathrm{CN})(\mathrm{CO})_{4}\right]^{-}$and the solvent $(\sim 205 \mathrm{~nm})$.

\section{[K(18-crown-6)][HFe $\left.(\mathrm{CN})_{2}(\mathrm{CO})_{3}\right],[\mathrm{K}(18-c r o w n-6)]\left[1 \mathrm{H}(\mathrm{CO})_{2}\right]$}

A solution of $0.050 \mathrm{~g},(0.063 \mathrm{mmol})$ of $\left[\mathrm{K}(18 \text {-crown-6) }]_{2}\left[\mathrm{Fe}(\mathrm{CN})_{2}(\mathrm{CO})_{3}\right]\right.$ in $5 \mathrm{~mL}$ of $\mathrm{MeCN}$ was treated with a solution of $0.064 \mathrm{~g}(0.063 \mathrm{mmol})$ of $\left[\mathrm{H}\left(\mathrm{OEt}_{2}\right)_{2}\right] \mathrm{BAr}_{4} \mathrm{~F}_{4}$ in $5 \mathrm{~mL}$ of MeCN, and the solution immediately became colorless. The product precipitated as a white powder upon addition of $40 \mathrm{~mL}$ of $\mathrm{Et}_{2} \mathrm{O}$. The powder was washed with $10 \mathrm{~mL}$ of $\mathrm{Et}_{2} \mathrm{O}$ to remove [K (18-crown-6)]BAr${ }_{4}$. IR and ${ }^{1} \mathrm{H}-\mathrm{NMR}$ spectra matched those previously reported. ${ }^{10}$

\section{[K(18-crown-6)][HFe $\left.(\mathrm{CN})_{2}(\mathrm{CO})_{2}\left(\mathrm{PPh}_{3}\right)\right]$, [K(18-crown-6)][1 $\left.\mathrm{H}(\mathrm{CO})\left(\mathrm{PPh}_{3}\right)\right]$}

A solution of $0.387 \mathrm{~g}(0.485 \mathrm{mmol})$ of $\left[\mathrm{K}(18 \text {-crown-6) }]_{2}\left[\mathrm{Fe}(\mathrm{CN})_{2}(\mathrm{CO})_{3}\right]\right.$ in $10 \mathrm{~mL}$ of $\mathrm{MeCN}$ was treated with $0.506 \mathrm{~g}(0.500 \mathrm{mmol})$ of $\left[\mathrm{H}\left(\mathrm{OEt}_{2}\right)_{2}\right] \mathrm{BAr}_{4}$, resulting in an immediate change from pale yellow to colorless. Addition of a solution of $0.13 \mathrm{~g}(0.50 \mathrm{mmol})$ of $\mathrm{PPh}_{3}$ in $5 \mathrm{~mL}$ of $\mathrm{MeCN}$ resulted in immediate gas evolution and a slight yellowing of the solution. Solvent was removed under vacuum to give a pale yellow powder. The powder was washed with 50 $\mathrm{mL}$ of $\mathrm{Et}_{2} \mathrm{O}$ to extract the co-formed salt and was dried under vacuum. Yield: $0.200 \mathrm{~g}(56 \%)$. $\operatorname{IR}(\mathrm{MeCN}): v_{\mathrm{CN}}=2111(\mathrm{w}), 2104(\mathrm{w}), 2092(\mathrm{w}) ; v_{\mathrm{CO}}=2011(\mathrm{~s}), 1960(\mathrm{~s}) .{ }^{1} \mathrm{H}$ NMR $(500$ $\mathrm{MHz}, \mathrm{CD}_{2} \mathrm{Cl}_{2}$ ): $\delta$ 7.35-7.75 (m, $15 \mathrm{H}, \mathrm{PPh}_{3}$ ), 3.61 (s, $24 \mathrm{H}, 18$-crown-6), -7.20 (d, $\left.49 \mathrm{~Hz}\right)$, -9.90 (d, $52 \mathrm{~Hz}),-11.25$ (d, $50 \mathrm{~Hz}) .{ }^{31} \mathrm{P}$ NMR $\left(202 \mathrm{MHz}, \mathrm{CD}_{2} \mathrm{Cl}_{2}\right): \delta 69.6$ (s), 68.3 (s), 61.9 (s). ESI MS (MeCN): m/z $427\left(\mathrm{HFe}(\mathrm{CN})_{2}(\mathrm{CO})_{2}\left(\mathrm{PPh}_{3}\right)^{-}\right)$.

\section{$[\mathrm{K}(18-\mathrm{crown}-6)]\left[\mathrm{HFe}(\mathrm{CN})_{2}(\mathrm{CO})_{2}\left\{\mathrm{P}(\mathrm{OPh})_{3}\right\}\right] \cdot[\mathrm{K}(18-$ crown-6)]Cl, [K(18-crown-6)][1 $\mathrm{H}(\mathrm{CO})\{\mathrm{P}$ $\left.\left.(\mathrm{OPh})_{3}\right\}\right] \cdot[\mathrm{K}(18-\mathrm{crown}-6)] \mathrm{Cl}$}

A solution of $0.066 \mathrm{~g}(0.083 \mathrm{mmol})$ of $\left[\mathrm{K}(18 \text {-crown-6) }]_{2}\left[\mathrm{Fe}(\mathrm{CN})_{2}(\mathrm{CO})_{3}\right]\right.$ in $10 \mathrm{~mL}$ of $\mathrm{MeCN}$ was treated with $0.085 \mathrm{~mL}$ of $1 \mathrm{M} \mathrm{HCl}$ in $\mathrm{Et}_{2} \mathrm{O}$, resulting in an immediate change from pale yellow to colorless. Addition of a solution of $0.025 \mathrm{~mL}(0.095 \mathrm{mmol})$ of $\mathrm{P}(\mathrm{OPh})_{3}$ in $5 \mathrm{~mL}$ of $\mathrm{MeCN}$ resulted in immediate gas evolution and a slight yellowing of the solution. Solvent was removed under vacuum to give a pale yellow powder and was dried under vacuum. Yield: $0.073 \mathrm{~g}(79 \%)$. IR (MeCN): $v_{\mathrm{CN}}=2118(\mathrm{w}), 2112(\mathrm{w}), 2101(\mathrm{vw}), 2080(\mathrm{vw}), 2086(\mathrm{vw})$; $v_{\mathrm{CO}}=2031$ (s), 1983 (s). ${ }^{1} \mathrm{H}$ NMR (500 MHz, $\left.\mathrm{CD}_{2} \mathrm{Cl}_{2}\right): \delta$ 7.7-7.0 (m, $\left.18 \mathrm{H}, \mathrm{P}(\mathrm{OPh})_{3}\right) ; 3.56$ (s, $48 \mathrm{H}, 18$-crown-6); -8.13 (d, $70 \mathrm{~Hz}, \mathrm{Fe}-H$ ); -8.45 (d, $70 \mathrm{~Hz}, \mathrm{Fe}-H) ;-12.60$ (d, $70 \mathrm{~Hz}, \mathrm{Fe}-$ H). ${ }^{31} \mathrm{P}$ NMR (202 MHz, $\left.\mathrm{CD}_{2} \mathrm{Cl}_{2}\right): \delta 172.3(\mathrm{~s}) ; 165.5(\mathrm{~s}) ; 130.1(\mathrm{~s})$.

\section{[K(18-crown-6)][HFe(CN) ${ }_{2}$ (CO)(dppv)], [K(18-crown-6)][1H(dppv)]}

A solution of $\left[\mathrm{K}(18 \text {-crown-6) }]_{2}\left[\mathrm{Fe}(\mathrm{CN})_{2}(\mathrm{CO})_{3}\right](0.254 \mathrm{~g}, 0.318 \mathrm{mmol})\right.$ in $\mathrm{MeCN}(10 \mathrm{~mL})$ was treated with a solution of $0.329 \mathrm{~g}(0.325 \mathrm{mmol})$ of $\left[\mathrm{H}\left(\mathrm{OEt}_{2}\right)_{2}\right] \mathrm{BAr}_{4}$ in $10 \mathrm{~mL}$ of MeCN, resulting in an immediate change from pale yellow to colorless. Addition of dppv $(0.143 \mathrm{~g}$, $0.362 \mathrm{mmol}$ ) resulted in immediate gas evolution and a color change to bright yellow. Solvent was removed under vacuum to give a pale yellow powder. Addition of $100 \mathrm{~mL}$ of $\mathrm{Et}_{2} \mathrm{O}$ gave 
a cloudy yellow solution. Upon concentrating the clear yellow filtrate by half and storing in the freezer at $-20^{\circ} \mathrm{C}$ overnight, the product precipitated as pale yellow microcrystals. The solid was filtered and dried under vacuum. Yield: $0.218 \mathrm{~g}(82 \%)$. IR $(\mathrm{MeCN}): v_{\mathrm{CN}}=2087(\mathrm{~m}), 2080$ $(\mathrm{m}) ; v_{\mathrm{CO}}=1936$ (s). ${ }^{1} \mathrm{H}$ NMR $\left(500 \mathrm{MHz}, \mathrm{CD}_{2} \mathrm{Cl}_{2}\right): \delta 7.33-7.91(\mathrm{~m}, 20 \mathrm{H}, \mathrm{Ph}), 3.59$ (s, 24, 18crown-6), 1.69 (br s, $2 \mathrm{H}, \mathrm{Ph}_{2} \mathrm{PCHCHPPh}_{2}$ ), -8.64 (t, Fe- $H, \mathrm{~J}_{\mathrm{HP}}=58 \mathrm{~Hz}$ ), -14.02 (dd, Fe- $H$, $\left.\mathrm{J}_{\mathrm{HP}}=59 \mathrm{~Hz}, \mathrm{~J}_{\mathrm{HP}}=49 \mathrm{~Hz}\right) .{ }^{31} \mathrm{P} \mathrm{NMR}\left(202 \mathrm{MHz}, \mathrm{CD}_{2} \mathrm{Cl}_{2}\right): \delta 108.2(\mathrm{~d}), 103.7(\mathrm{~s}), 97.2(\mathrm{~d})$. ESI MS (MeCN): m/z $533\left(\mathrm{HFe}(\mathrm{CN})_{2}(\mathrm{CO})(\mathrm{dppv})^{-}\right)$. Anal. Calcd for $\mathrm{C}_{41} \mathrm{H}_{47} \mathrm{FeKN}_{2} \mathrm{O}_{7} \mathrm{P}_{2}: \mathrm{C}$, 58.85; H, 5.66; N, 3.35. Found: C, 58.81; H, 5.27; N, 3.65.

\section{Protonation of [K(18-crown-6)][1(dppv)]}

In MeCN-A solution of [K(18-crown-6)][1H(dppv)] $(0.102 \mathrm{~g}, 0.123 \mathrm{mmol})$ in $10 \mathrm{~mL}$ of $\mathrm{MeCN}$ was treated with $\mathrm{HCl}\left(1.0 \mathrm{M}\right.$ in $\left.\mathrm{Et}_{2} \mathrm{O}, 0.125 \mathrm{~mL}\right)$. Gas evolution and a peak for free $\mathrm{H}_{2}$ at $\delta 4.56$ in the ${ }^{1} \mathrm{H}$ NMR spectrum were observed. The product precipitated from solution as a yellow powder. The solid was isolated by filtration and recrystallized from $5 \mathrm{~mL}$ of $\mathrm{CH}_{2} \mathrm{Cl}_{2}$ upon addition of $50 \mathrm{~mL}$ of hexane. Yield: $0.078 \mathrm{~g}(76 \%)$. IR $(\mathrm{MeCN}): v_{\mathrm{CN}}=2111$ (w), 2104 (w sh); $v_{\mathrm{CO}}=2004$ (s). ${ }^{1} \mathrm{H}$ NMR (500 MHz, $\mathrm{CD}_{2} \mathrm{Cl}_{2}$ ): $\delta 8.14$ (s, 1H, CH); 8.03 (s, $1 \mathrm{H}, \mathrm{CH}) ; 8.0-7.3(\mathrm{~m}, 20 \mathrm{H}, \mathrm{Ph}), 2.16\left(\mathrm{~s}, 3 \mathrm{H}, \mathrm{NCCH}_{3}\right) .{ }^{31} \mathrm{P} \mathrm{NMR}\left(202 \mathrm{MHz}, \mathrm{CDCl}_{3}\right): \delta 84.1$ (s) $)^{\sim}$ Anal. Calcd for $\mathrm{C}_{31} \mathrm{H}_{25} \mathrm{FeN}_{3} \mathrm{OP}_{2}$ : C, 64.94; H, 4.39; N, 7.33. Found: C, 64.12; H, 4.19; $\mathrm{N}, 8.01$.

In $\mathbf{C H}_{\mathbf{2}} \mathbf{C l}_{\mathbf{2}}$-A solution of $0.050 \mathrm{~g}(0.060 \mathrm{mmol})$ of [K(18-crown-6)][1H(dppv)] in $10 \mathrm{~mL}$ of $\mathrm{CH}_{2} \mathrm{Cl}_{2}$ was treated with a solution of $0.067 \mathrm{~g}(0.066 \mathrm{mmol})$ of $\left[\mathrm{H}\left(\mathrm{OEt}_{2}\right)_{2}\right] \mathrm{BAr} \mathrm{F}_{4}$ in $10 \mathrm{~mL}$ of $\mathrm{CH}_{2} \mathrm{Cl}_{2}$. Gas evolution was observed. IR $\left(\mathrm{CH}_{2} \mathrm{Cl}_{2}\right): v_{\mathrm{CN}}=2110(\mathrm{w}, \mathrm{br}) ; v_{\mathrm{CO}}=2004(\mathrm{~s})$. Solvent was removed under vacuum to give a yellow powder. Upon dissolving the yellow powder in $10 \mathrm{~mL}$ of $\mathrm{MeCN}$, the IR spectrum was indistinguishable from that of $\mathbf{1}(\mathrm{NCMe})(\mathrm{dppv})$.

\section{[K(18-crown-6) $]_{2}\left[\mathrm{HFe}(\mathrm{CN})_{3}(\mathrm{CO})_{2}\right]^{\cdot} \mathrm{MeCN},[\mathrm{K}(18-c r o w n-6)]_{2}[1 \mathrm{H}(\mathrm{CN})(\mathrm{CO})]^{-} \mathrm{MeCN}$}

A solution of $\left[\mathrm{K}(18 \text {-crown-6) }]_{2}\left[\mathrm{Fe}(\mathrm{CN})_{2}(\mathrm{CO})_{3}\right](0.0923 \mathrm{~g}, 0.116 \mathrm{mmol})\right.$ in $5 \mathrm{~mL}$ of MeCN was treated with $60 \mu \mathrm{L}(0.12 \mathrm{mmol})$ of a $2.0 \mathrm{M}$ solution of $\mathrm{HCl}$ in $\mathrm{Et}_{2} \mathrm{O}$, giving a colorless solution of the hydride. This solution was treated with $\mathrm{PPh}_{3}(0.0601 \mathrm{~g}, 0.229 \mathrm{mmol})$. When gas evolution ceased, a solution of $0.0083 \mathrm{~g}(0.13 \mathrm{mmol}) \mathrm{KCN}$ in $\sim 5 \mathrm{~mL}$ of $\mathrm{MeOH}$ was added to the reaction mixture. After stirring for $30 \mathrm{~min}$, the solvent was removed under vacuum to give a pale yellow powder. The product was extracted with $5 \mathrm{~mL}$ of $\mathrm{MeCN}$, and the resulting pale yellow solution was layered with $25 \mathrm{~mL}$ of $\mathrm{Et}_{2} \mathrm{O}$. The pale yellow crystalline solid was isolated by filtration and washed with $60 \mathrm{~mL}$ of $\mathrm{Et}_{2} \mathrm{O}$ to remove $\mathrm{PPh}_{3}$. Yield: $0.045 \mathrm{~g} \mathrm{(49 \% ).}$ IR $(\mathrm{MeCN}): v_{\mathrm{CN}}=2098(\mathrm{w}), 2086(\mathrm{w}) ; v_{\mathrm{CO}}=1992(\mathrm{~s}), 1935$ (s). ${ }^{1} \mathrm{H}$ NMR $(500 \mathrm{MHz}$, $\mathrm{CD}_{2} \mathrm{Cl}_{2}$ ): $\delta 3.58$ (s, $48 \mathrm{H}, 18$-crown-6), 2.09 (s, $3 \mathrm{H}, \mathrm{CH}_{3} \mathrm{CN}$ ), -7.47 (s, Fe-H), -11.65 (s, Fe$H$ ), -13.04 (s, Fe- H). Anal. Calcd for $\mathrm{C}_{29} \mathrm{H}_{49} \mathrm{FeK}_{2} \mathrm{~N}_{3} \mathrm{O}_{14}{ }^{\cdot} \mathrm{C}_{2} \mathrm{H}_{3} \mathrm{~N}$ : C, 44.39; H, 6.25; N, 6.68. Found: C, 43.86; H, 5.96; N, 6.85 .

\section{Protonation of $[\mathrm{K}(18-\mathrm{crown}-6)]\left[\mathrm{HFe}(\mathrm{CN})_{3}(\mathrm{CO})_{2}\right]$}

A solution of $\left[\mathrm{K}(18 \text {-crown-6) }]_{2}[1 \mathrm{H}(\mathrm{CN})(\mathrm{CO})](0.030 \mathrm{~g}, 0.038 \mathrm{mmol})\right.$ in $5 \mathrm{~mL}$ of $\mathrm{MeCN}$ was treated with $0.040 \mathrm{~mL}$ of $1 \mathrm{M} \mathrm{HCl}$ in $\mathrm{Et}_{2} \mathrm{O}$. Gas evolution was observed, and the solution became darker yellow. Solvent was removed under vacuum to give a yellow solid. Yield: 0.028 $\mathrm{g}(84 \%)$. IR (MeCN): $v_{\mathrm{CN}}=2133(\mathrm{w}), 2127(\mathrm{w}), 2118(\mathrm{w}) ; v_{\mathrm{CO}}=2068(\mathrm{~s}), 2023$ (s). These data match those previously reported by Liaw for $(\mathrm{PPN})_{2}\left[\mathrm{Fe}(\mathrm{CN})_{3}(\mathrm{NCMe})(\mathrm{CO})_{2}\right]^{12}$

\section{[K(18-crown-6)][MeFe(CN) $\left.{ }_{2}(\mathrm{CO})_{3}\right]$, [K(18-crown-6)][1 Me(CO) $\left.)_{2}\right]$}

A solution of $0.086 \mathrm{~g}(0.11 \mathrm{mmol})$ of $\left[\mathrm{K}(18 \text {-crown-6) }]_{2}\left[\mathrm{Fe}(\mathrm{CN})_{2}(\mathrm{CO})_{3}\right]\right.$ in $10 \mathrm{~mL}$ of $\mathrm{CH}_{2} \mathrm{Cl}_{2}$ was treated with $0.011 \mathrm{~mL}(0.10 \mathrm{mmol})$ of MeOTf resulting in a color change from pale yellow 
to colorless. IR (MeCN): $v_{\mathrm{CN}}=2109(\mathrm{w}), 2083(\mathrm{w}), 2074(\mathrm{w}) ; v_{\mathrm{CO}}=2016(\mathrm{~s})$. $\mathrm{ESI} \mathrm{MS}(\mathrm{MeCN})$ : $\mathrm{m} / \mathrm{z} 207\left(\left[\mathrm{MeFe}(\mathrm{CN})_{2}(\mathrm{CO})_{3}\right]^{-}\right)$.

\section{$\left(\mathrm{Et}_{4} \mathrm{~N}\right)\left[\mathrm{Fe}(\mathrm{CN})_{2}(\mathrm{COMe})(\mathrm{CO})(\mathrm{dppv})\right], \mathrm{Et}_{\mathbf{4}} \mathrm{N}[\mathrm{IAc}(\mathrm{dppv})]$}

A solution of $0.250 \mathrm{~g}(0.315 \mathrm{mmol})$ of $\left(\mathrm{Et}_{4} \mathrm{~N}\right)_{2}\left[\mathrm{Fe}(\mathrm{CN})_{2}(\mathrm{CO}) 3\right]$ in $20 \mathrm{~mL}$ of $\mathrm{CH}_{2} \mathrm{Cl}_{2}$ was treated with $0.034 \mathrm{~mL}(0.31 \mathrm{mmol})$ of MeOTf. Addition of $0.134 \mathrm{~g}(0.337 \mathrm{mmol})$ of dppv resulted in a color change to light yellow-orange. The volume of the solution was reduced by half, and the product was precipitated from solution upon addition of $40 \mathrm{~mL}$ of $\mathrm{Et}_{2} \mathrm{O}$. The bright yellow solid was washed with $20 \mathrm{~mL}$ of benzene to remove a yellow impurity and dried under vacuum. The solid was dissolved in $5 \mathrm{~mL}$ of $\mathrm{CH}_{2} \mathrm{Cl}_{2}$, and an equal volume of water was added to extract $\mathrm{Et}_{4} \mathrm{NI}$. The clear, yellow $\mathrm{CH}_{2} \mathrm{Cl}_{2}$ layer was isolated and taken to dryness. Yield: $0.130 \mathrm{~g}(48 \%)$. IR $(\mathrm{MeCN}): v_{\mathrm{CO}}=2077(\mathrm{~m}) ; v_{\mathrm{CO}}=1936(\mathrm{~s}), 1592(\mathrm{~m}) .{ }^{1} \mathrm{H}$ NMR $(500 \mathrm{MHz}$, $\mathrm{CD}_{3} \mathrm{CN}$ ): $\delta$ 7.9-7.0 (m, $22 \mathrm{H}$, dppv), 2.59 (s, $\left.3 \mathrm{H}, \mathrm{CH}_{3}\right) .{ }^{31} \mathrm{P} \mathrm{NMR}\left(202 \mathrm{MHz}, \mathrm{CD}_{3} \mathrm{CN}\right): \delta 73.3$ (br s), 72.1 (d, $3 \mathrm{~Hz}), 70.7$ (br s), 69.9 (d, $3 \mathrm{~Hz})$. ESI MS (MeCN): m/z 575 ([Fe(CN) $)_{2}(\mathrm{COMe})$ $(\mathrm{CO})(\mathrm{dppv})]^{-}$). Anal. Calcd for $\mathrm{C}_{3} 9 \mathrm{H}_{45} \mathrm{FeN}_{3} \mathrm{O}_{2} \mathrm{P}_{2}: \mathrm{C}, 66.39 ; \mathrm{H}, 6.43 ; \mathrm{N}, 5.96$. Found: C, 65.41; $\mathrm{H}, 6.37 ; \mathrm{N}, 5.79$. A MeCN solution of the complex remained unchanged (no decarbonylation) after heating at reflux for $12 \mathrm{~h}$.

\section{[K(18-crown-6)][Fe(CN)(CO) $\left.)_{3}(\mathrm{CNCOPh})\right]$}

A solution of $\left[\mathrm{K}(18 \text {-crown-6) }]_{2}\left[\mathrm{Fe}(\mathrm{CN})_{2}(\mathrm{CO})_{3}\right](0.097 \mathrm{~g}, 0.12 \mathrm{mmol})\right.$ in $3 \mathrm{~mL}$ of $\mathrm{MeCN}$ was treated with $\mathrm{PhCOCl}(14 \square \mathrm{L}, 0.12 \mathrm{mmol})$, resulting in an immediate change from pale yellow to deep red. Solvent was removed under vaccum to give a dark red oil. The oil was extracted with $30 \mathrm{~mL}$ of $\mathrm{Et}_{2} \mathrm{O}$. The resulting solution was concentrated to approximately $2 \mathrm{~mL}$, and the product was precipitated upon addition of $20 \mathrm{~mL}$ of hexane. The solid was isolated by filtration and dried under vacuum. Yield: $30 \mathrm{mg}(42 \%)$. IR $(\mathrm{MeCN}): v_{\mathrm{CO}}=2107(\mathrm{w}), 2035(\mathrm{~m}) ; v_{\mathrm{CO}}=$ 1947 (s, sh), 1932 (vs), 1661 (m). ${ }^{1} \mathrm{H}$ NMR (500 MHz, CD ${ }_{3} \mathrm{CN}$ ): $\delta 8.18$ (d, $2 \mathrm{H}, o-\mathrm{Ph}$ ), 7.67 (t, $1 \mathrm{H}, p$-Ph), 7.54 (t, $2 \mathrm{H}, m$-Ph), 3.56 (s, $24 \mathrm{H}, 18$-crown-6). ESI MS (MeCN): m/z 297 ([Fe $\left.\left.(\mathrm{CN})(\mathrm{CNCOPh})(\mathrm{CO})_{3}\right]^{-}\right)$. Anal. Calcd for $\mathrm{C}_{24} \mathrm{H}_{29} \mathrm{FeKN}_{2} \mathrm{O}_{10}$ : C, 48.01; H, 4.87; N, 4.67.

Found: $\mathrm{C}, 47.85 ; \mathrm{H}, 4.90 ; \mathrm{N}, 4.69$. The corresponding acetyl derivative was prepared similarly using $\mathrm{MeCOCl}$ to give yellow solids with similar spectroscopic features.

\section{Oxidation of $[\mathrm{K}(18-\mathrm{crown}-6)]_{2}\left[\mathrm{Fe}(\mathrm{CN})_{2}(\mathrm{CO})_{3}\right]$}

A solution of $0.048 \mathrm{~g}(0.060 \mathrm{mmol})$ of $[\mathrm{K}(18 \text {-crown- } 6)]_{2}\left[\mathrm{Fe}(\mathrm{CN})_{2}(\mathrm{CO})_{3}\right]$ in $10 \mathrm{~mL}$ of $\mathrm{MeCN}$ was treated with a solution of $0.040 \mathrm{~g}(0.12 \mathrm{mmol}) \mathrm{of} \mathrm{FePF}_{6}$ in $10 \mathrm{~mL}$ of MeCN, giving a clear, yellow solution. The IR spectrum of the reaction mixture was difficult to interpret due to a large number of overlapping peaks; however, ESI-MS of the reaction mixture showed a significant signal for $\left[\mathrm{Fe}(\mathrm{CN})_{3}(\mathrm{CO})_{3}\right]^{-}$.

\section{Crystallography}

Crystals were mounted to a thin glass fiber using Paratone-N oil (Exxon). Data, collected at $193 \mathrm{~K}$ on a Siemens CCD diffractometer, were filtered to remove statistical outliers. The integration software (SAINT) was used to test for crystal decay as a bilinear function of X-ray exposure time and $\sin (\theta)$. The data were solved using SHELXTL (Table 2) by direct methods for $\mathrm{Fe}(\mathrm{CN})_{2}(\mathrm{NCMe})(\mathrm{CO})(\mathrm{dppv})$ and $\left[\mathrm{K}\left(18\right.\right.$-crown-6)][HFe $\left.(\mathrm{CN})_{3}(\mathrm{CO})_{2}\right] \bullet \mathrm{MeCN}$ and by dual methods for $\left[\mathrm{K}\left(18\right.\right.$-crown-6)][ $\left.\mathrm{HFe}(\mathrm{CN})_{2}(\mathrm{CO})(\mathrm{dppv})\right] \cdot \mathrm{MeCN} \cdot \mathrm{Et}_{2} \mathrm{O}$; atomic positions were deduced from an $E$ map or by an unweighted difference Fourier synthesis. Methyl hydrogen atom $U$ 's were assigned as $1.5 U_{\text {eq }}$ of the carrier atom; remaining hydrogen atom $U$ 's were assigned as 1.2 times carrier $U_{\text {eq }}$. Metal hydride hydrogen atoms were surfaced in a late Fourier difference map and were independently refined without restraints. Non-hydrogen atoms were refined anisotropically. Successful convergence of the full-matrix least-squares refinement of $F 2$ was indicated by the maximum shift/error for the final cycle. 


\section{Supplementary Material}

Refer to Web version on PubMed Central for supplementary material.

\section{Acknowledgement}

This research was sponsored by the NIH.

\section{References}

1. Cammack, R.; Frey, M.; Robson, R. Hydrogen as a Fuel: Learning from Nature. London: Taylor \& Francis; 2001.

2. Linden E, Burgdorf T, Bernhard M, Bleijlevens B, Friedrich B, Albracht S. J. Biol. Inorg. Chem 2004;9:616-626. [PubMed: 15164270]

3. Fontecilla-Camps JC, Volbeda A, Cavazza C, Nicolet Y. Chem. Rev 2007;107:4273-4303. [PubMed: 17850165]

4. Brecht M, van Gastel M, Buhrke T, Friedrich B, Lubitz W. J. Am. Chem. Soc 2003;125:13075-13083. [PubMed: 14570480]

5. Fehlhammer WP, Fritz M. Chem. Rev 1993;93:1243-1280.

6. Bianchini C, Laschi F, Ottaviani MF, Peruzzini M, Zanello P, Zanobini F. Organometallics 1989;8:893-899.

7. Gloaguen F, Lawrence JD, Rauchfuss TB. J. Am. Chem. Soc 2001;123:9476-9477. [PubMed: 11562244]Schmidt M, Contakes SM, Rauchfuss TB. J. Am. Chem. Soc 1999;121:9736-9737.

8. Boyke CA Ph.D. Thesis, University of Illinois at Urbana-Champaign. 2006

9. del Rosario R, Stuhl LS. Tetrahedron Lett 1982;23:3999-4002.Joo F, Alper H. Organometallics 1985;4:1775-1778.

10. Kayal A, Rauchfuss TB. Inorg. Chem 2003;42:5046-5048. [PubMed: 12924874]

11. Ohki Y, Yasumura K, Kuge K, Tanino S, Ando M, Li Z, Tatsumi K. Proc. Natl. Acad. Sci. USA 2008;105:7652-7657. [PubMed: 18511566]Liaw W-F, Tsai W-T, Gau H-B, Lee C-M, Chou S-Y, Chen W-Y, Lee G-H. Inorg. Chem 2003;42:2783-2788. [PubMed: 12691589]Liaw W, Lee J, Gau H, Chen C, Jung S, Hung C, Chen W, Hu C, Lee G. J. Am. Chem. Soc 2002;124:1680-1688. [PubMed: 11853444]Liaw W, Lee N, Chen C, Lee C, Lee G, Peng S. J. Am. Chem. Soc 2000;122:488-494.Pal S, Ohki Y, Kuge K, Tatsumi K. Chem. Asian J 2009;2Li Z, Ohki Y, Tatsumi K. J. Am. Chem. Soc 2005;127:8950-8951. [PubMed: 15969562]van der Vlugt, JI.; Meyer, F. Met. Ions Life Sci. Sigel, A.; Sigel, H.; Sigel, RKO., editors. Vol. Vol. 2. London: J. Wiley; 2007. p. 181-240. Ogo S, Kabe T, Uehara K, Kure B, Nishimura T, Menon SC, Harada R, Fukuzumi S. Science 2007;316:585-588. [PubMed: 17463285]

12. Chen C, Chang Y, Yang C, Chen T, Lee C, Liaw W. Dalton Trans 2004:137-143. [PubMed: 15356752]

13. Jiang J, Koch SA. Inorg. Chem 2002;41:158-160. [PubMed: 11800601]

14. Jiang J, Koch SA. Angew. Chem. Int. Ed 2001;40:2629-2631.Jiang J, Acunzo A, Koch SA. J. Am. Chem. Soc 2001;123:12109-12110. [PubMed: 11724629]

15. Ash CE, Delord T, Simmons D, Darensbourg MY. Organometallics 1986;5:17-25.

16. Moore EJ, Sullivan JM, Norton JR. J. Am. Chem. Soc 1986;108:2257-2263.

17. Lai C-H, Lee W-Z, Miller ML, Reibenspies JH, Darensbourg DJ, Darensbourg MY. J. Am. Chem. Soc 1998;120:10103-10114.

18. Augustin-Nowacka D, Chmurzyñski L. Anal. Chim. Acta 1999;381:215-220.

19. Kristjansdottir SS, Moody AE, Weberg RT, Norton JR. Organometallics 1988;7:1983-1987.

20. Chen C-H, Chang Y-S, Yang C-Y, Chen T-N, Lee C-M, Liaw W-F. Dalton Trans 2004:137-143. [PubMed: 15356752]

21. Albers MO, Coville NJ, Singleton E. J. Chem. Soc. Dalton Trans 1982:1069-1079.

22. Cardaci G, Reichenbach G, Bellachioma G. Inorg. Chem 1984;23:2936-2940. 
23. Simonneaux G, Lemaux P, Jaouen G, Dabard R. Inorg. Chem 1979;18:3167-3170.Carter SJ, Foxman BM, Stuhl LS. Organometallics 1986;5:1918-1920.

24. Guastalla G, Halpern J, Pribanic M. J. Amer. Chem. Soc 1972;94:1575-1577.Halpern J, Guastalla G, Bercaw J. Coord. Chem. Rev 1972;8:167-173.Halpern J, Guastalla G, Bercaw J. Coord. Chem. Rev 1972;8:167-173.

25. Contakes SM, Hsu SCN, Rauchfuss TB, Wilson SR. Inorg. Chem 2002;41:1670-1678. [PubMed: 11896739]

26. Gloaguen F, Lawrence JD, Rauchfuss TB, Bénard M, Rohmer M-M. Inorg. Chem 2002;41:65736582. [PubMed: 12470052]

27. de Lacey AL, Hatchikian EC, Volbeda A, Frey M, Fontecilla-Camps JC, Fernandez VM. J. Am. Chem. Soc 1997;119:7181-7189.

28. Pearson RG, Walker HW, Mauermann H, Ford PC. Inorg. Chem 1981;20:2741-2743.

29. Sowa JR Jr, Zanotti V, Facchin G, Angelici RJ. J. Am. Chem. Soc 1991;113:9185-9192.

30. Connelly NG, Somers KR. J. Organomet. Chem 1976;113:C39-C41.

31. Toma HE, Malin JM. Inorg. Chem 1973;12:1039-1045.

32. Nataro C, Chen J, Angelici RJ. Inorg. Chem 1998;37:1868-1875.

33. Angelici RJ. Acc. Chem. Res 1995;28:51-60.

34. Kubas, GJ. Metal Dihydrogen and $\sigma$-Bond Complexes. New York: Kluwer Academic/Plenum; 2001.

35. Fauque G, Peck HD Jr, Moura JJG, Huynh BH, Berlier Y, DerVartanian DV, Teixeira M, Przybyla AE, Lespinat PA. FEMS Microbiol. Rev 1988;54:299-344. [PubMed: 3078655]

36. Goldet G, Wait AF, Cracknell JA, Vincent KA, Ludwig M, Lenz O, Friedrich B, Armstrong FA. J. Am. Chem. Soc 2008;130:11106-11113. [PubMed: 18661984]

37. Abdur-Rashid K, Fong TP, Greaves B, Gusev DG, Hinman JG, Landau SE, Lough AJ, Morris RH. J. Am. Chem. Soc 2000;122:9155-9171. 


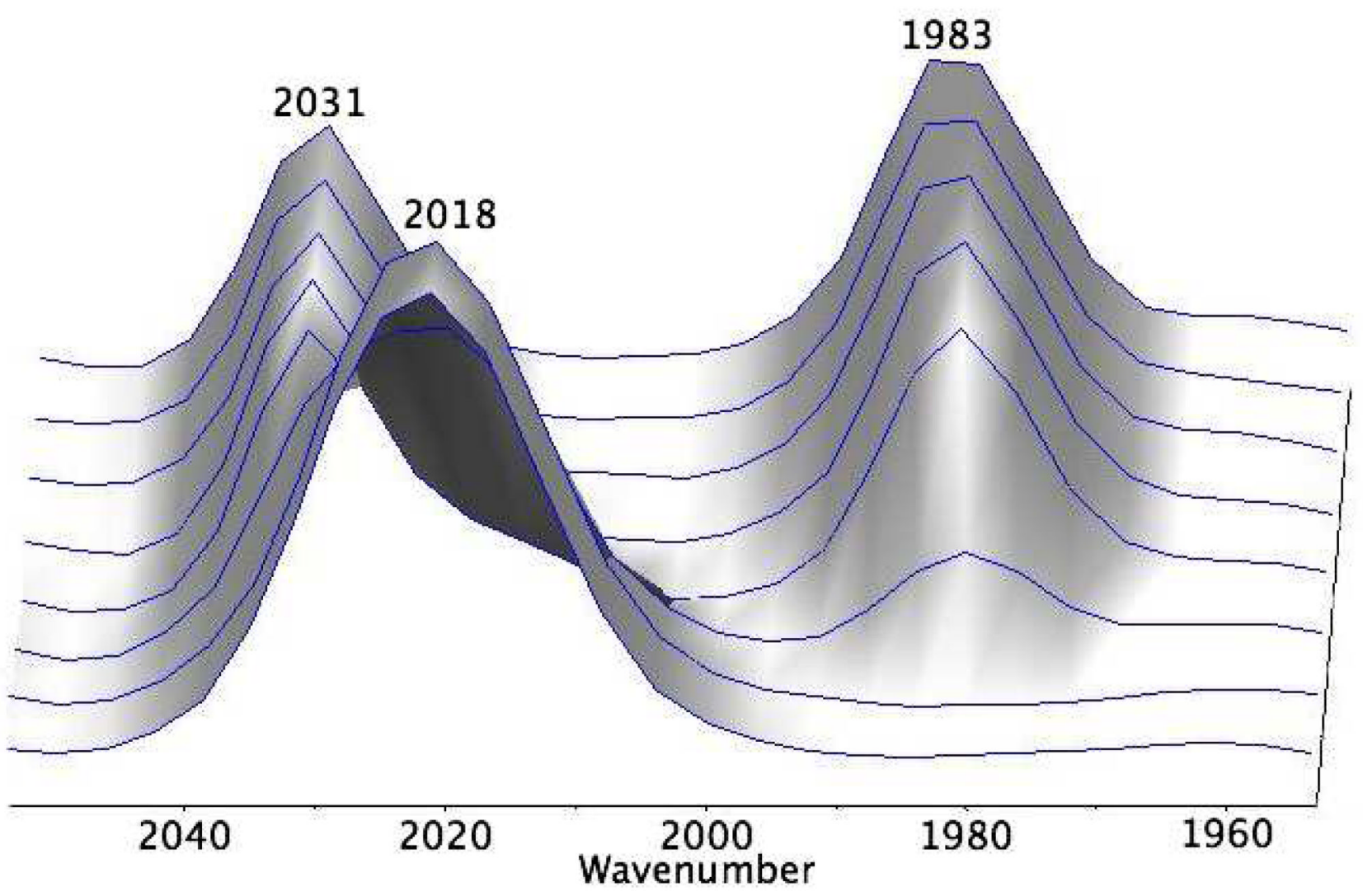

Figure 1.

IR spectra $\left(v_{\mathrm{CO}}\right.$ region only) for the reaction of $\left[\mathrm{K}\left(18\right.\right.$-crown-6)][1 $\left.1 \mathrm{H}(\mathrm{CO})_{2}\right]$ with 10 equiv of $\mathrm{P}(\mathrm{OPh})_{3}$ in $\mathrm{MeCN}$ solution at $20{ }^{\circ} \mathrm{C}$. 


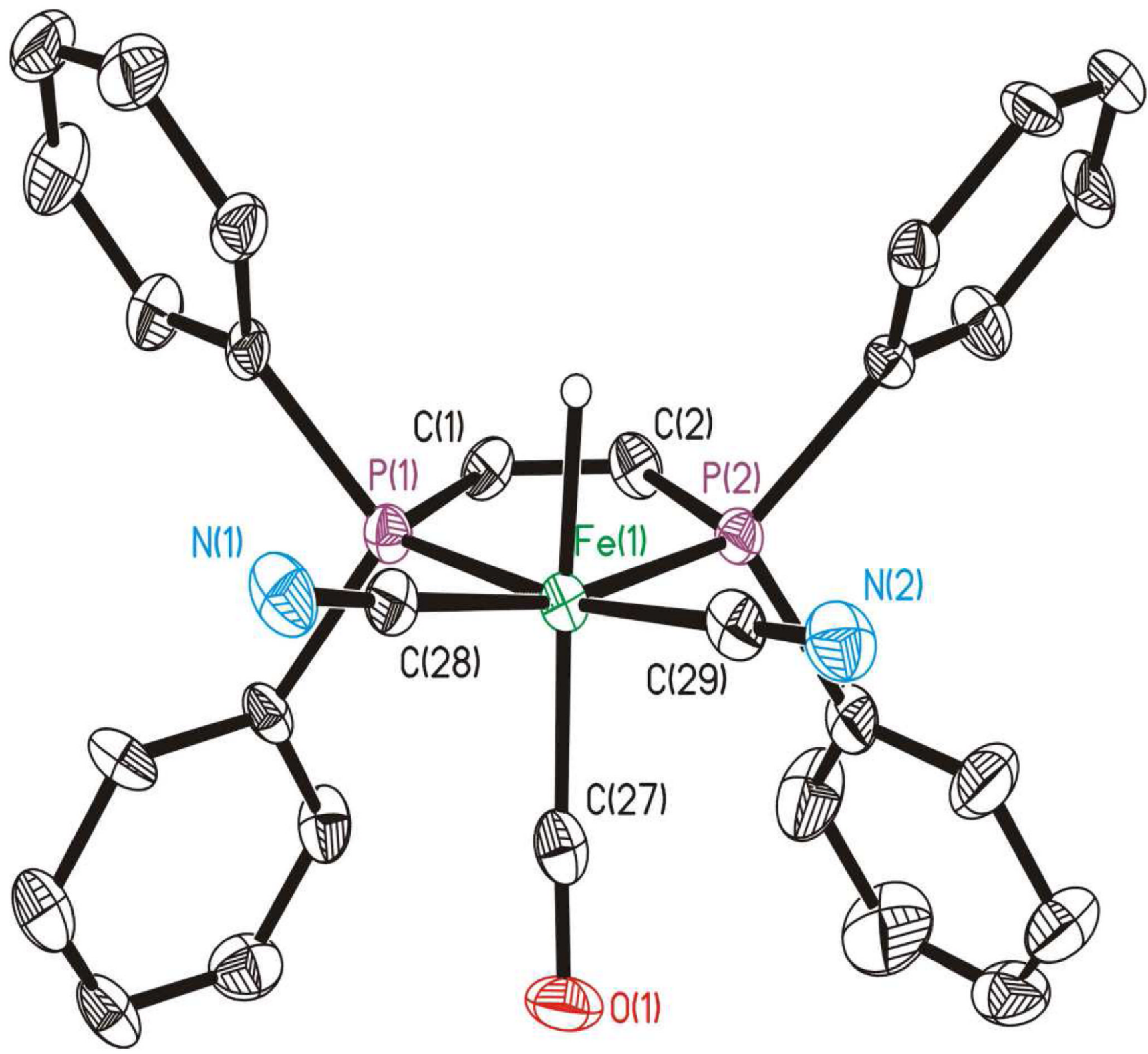

Figure 2.

Molecular structure of the anion $[1 \mathrm{H}(\mathrm{dppv})]^{-}$with thermal ellipsoids set at the $35 \%$ probability level. Cation, solvates, and non-hydride hydrogen atoms were omitted for clarity. 


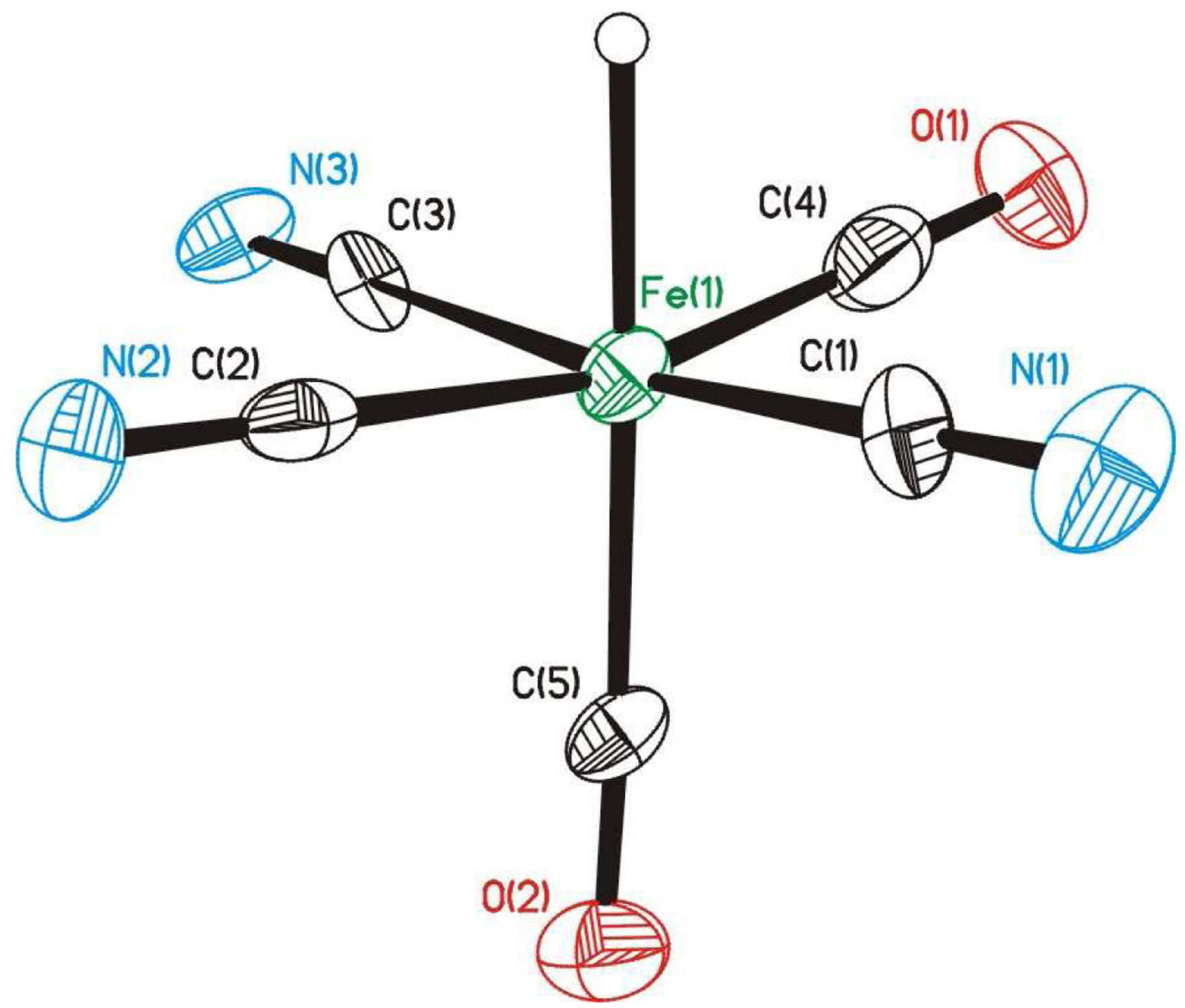

Figure 3.

Molecular structure of the anion $[1 \mathrm{H}(\mathrm{CN})(\mathrm{CO})]^{2-}$ with thermal ellipsoids set at the $35 \%$ probability level. $\left[\mathrm{K}(18 \text {-crown-6) }]^{+}\right.$cations and acetonitrile solvate was omitted for clarity. 


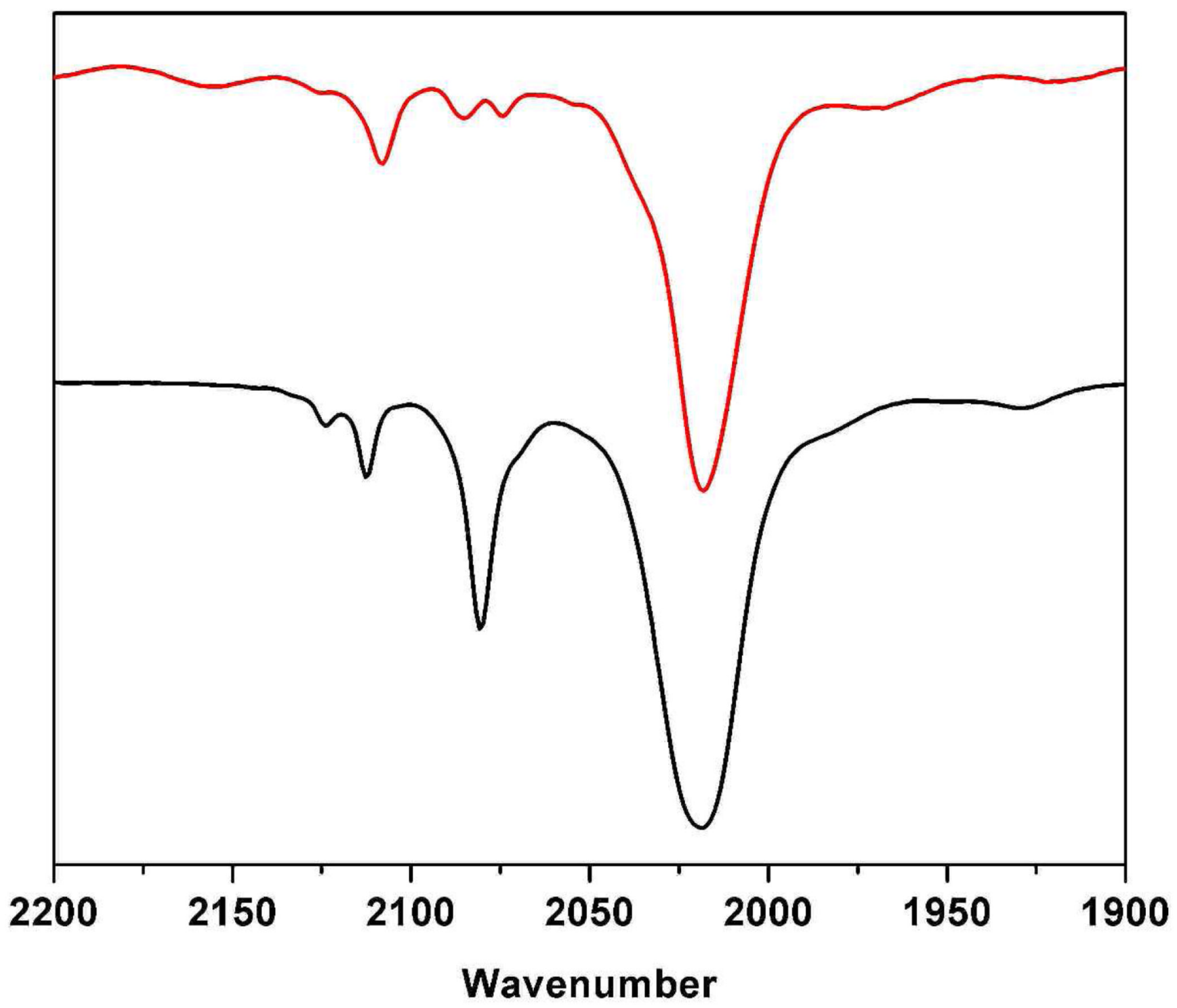

Figure 4.

Solution $(\mathrm{MeCN})$ IR spectra of $\left[\mathrm{K}\left(18\right.\right.$-crown-6)][1 $\left.\mathrm{H}(\mathrm{CO})_{2}\right]$ (bottom) and [K(18-crown-6)] $\left[1 \mathrm{Me}(\mathrm{CO})_{2}\right]$ (top). 

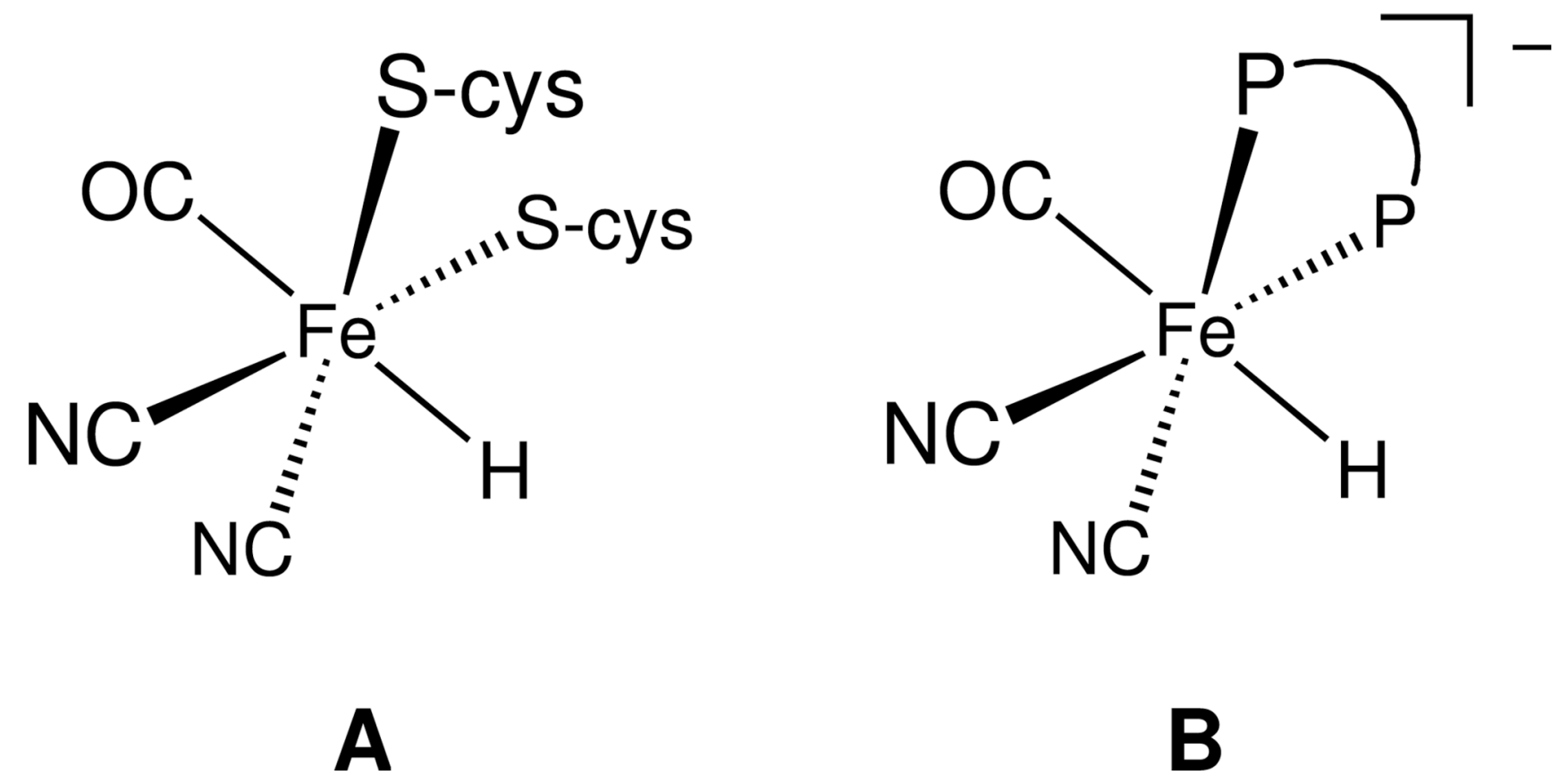

Figure 5.

Fe site of the Ni-R and Ni-C states in the $[\mathrm{NiFe}]-$ hydrogenases $(\mathrm{A})$ and $[\mathbf{1 H}(\mathrm{dppv})]^{-}(\mathrm{B})$ 


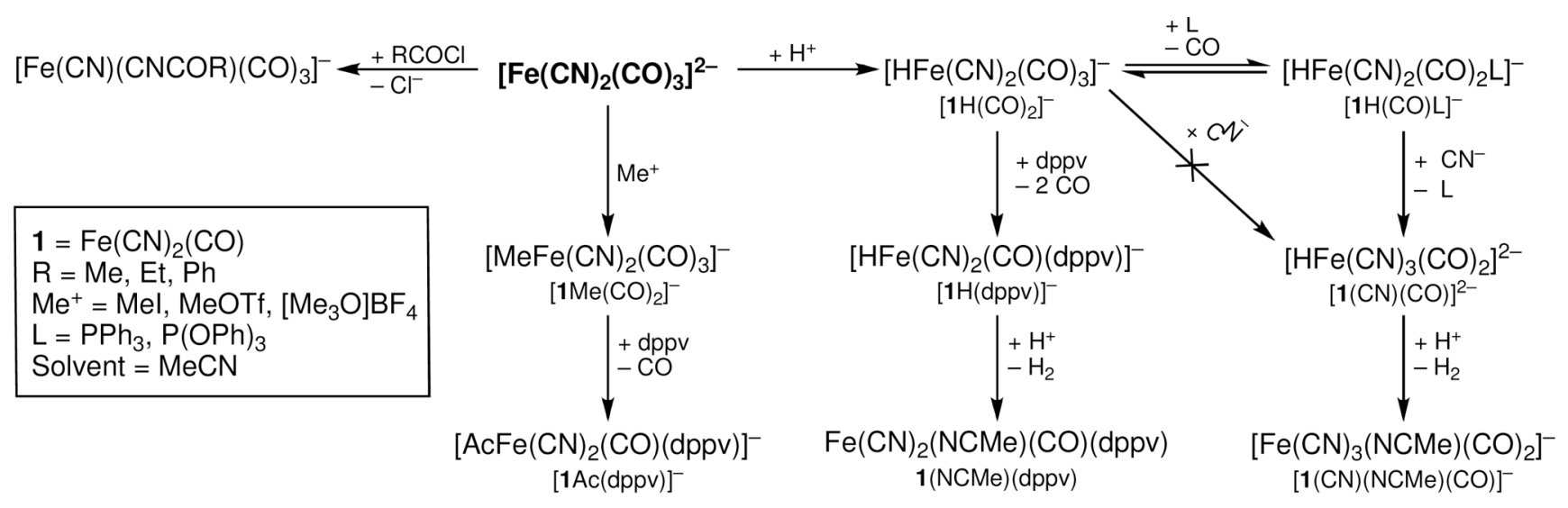

Scheme 1. 


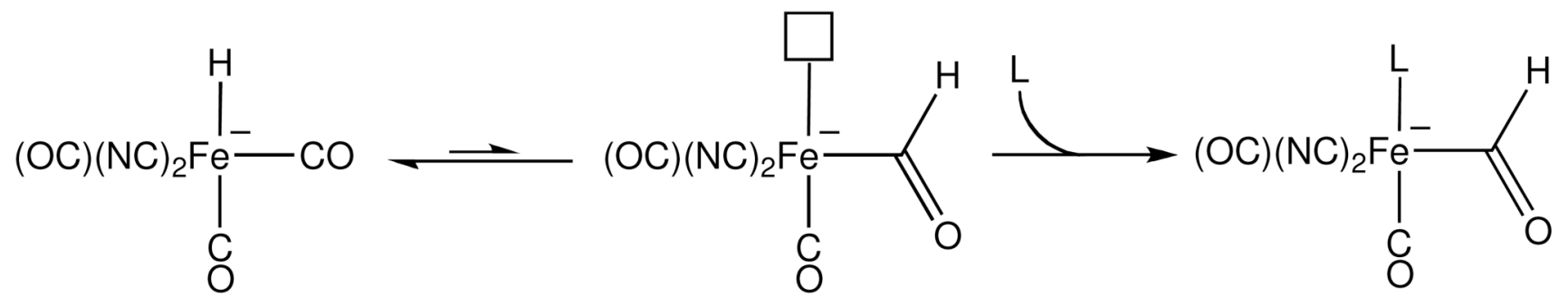
$\left[\mathbf{1 H}(\mathrm{CO})_{2}\right]^{-}$

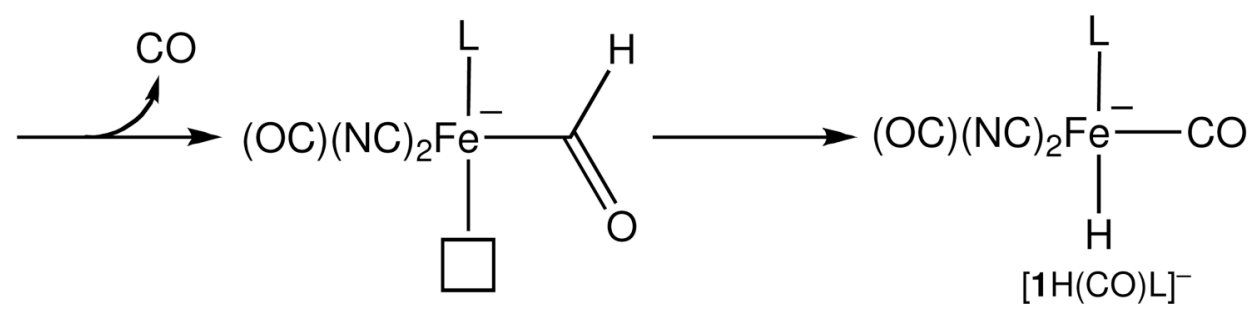

Scheme 2. 
Table 1

Bond Lengths ( $\mathrm{A})$ for [K(18-crown-6)][1H(dppv)] and 1(NCMe)(dppv).

\begin{tabular}{llll}
\hline & {$[\mathbf{1}(\mathbf{d p p v})]^{-}$} & & 1(NCMe)(dppv) \\
\hline $\mathrm{Fe}(1)-\mathrm{P}(1)$ & $2.169(2)$ & $\mathrm{Fe}(1)-\mathrm{P}(1)$ & $2.2563(9)$ \\
$\mathrm{Fe}(1)-\mathrm{P}(2)$ & $2.169(2)$ & $\mathrm{Fe}(1)-\mathrm{P}(1 \mathrm{~A})$ & $2.2563(9)$ \\
$\mathrm{Fe}(1)-\mathrm{C}(27)$ & $1.770(10)$ & $\mathrm{Fe}(1)-\mathrm{C}(2)$ & $1.748(4)$ \\
$\mathrm{Fe}(1)-\mathrm{C}(28)$ & $\mathrm{Fe}(1)-\mathrm{C}(3)$ & $1.938(3)$ \\
$\mathrm{Fe}(1)-\mathrm{C}(29)$ & $1.915(8)$ & $\mathrm{Fe}(1)-\mathrm{C}(3 \mathrm{~A})$ & $1.938(3)$ \\
$\mathrm{Fe}(1)-\mathrm{H}(1 \mathrm{~A})$ & $1.914(9)$ & $\mathrm{Fe}(1)-\mathrm{N}(2)$ & $1.980(4)$ \\
$\mathrm{C}(27)-\mathrm{O}(1)$ & $1.51(6)$ & $\mathrm{C}(2)-\mathrm{O}(1)$ & $1.156(5)$ \\
$\mathrm{C}(28)-\mathrm{N}(1)$ & $1.154(9)$ & $\mathrm{C}(3)-\mathrm{N}(1)$ & $1.153(4)$ \\
$\mathrm{C}(29)-\mathrm{N}(2)$ & $1.162(8)$ & $\mathrm{C}(3 \mathrm{~A})-\mathrm{N}(1 \mathrm{~A})$ & $1.153(4)$ \\
\hline
\end{tabular}

